University of New Hampshire

University of New Hampshire Scholars' Repository

Earth Systems Research Center

Institute for the Study of Earth, Oceans, and

Space (EOS)

$10-17-2016$

\title{
Evapotranspiration and water use efficiency in relation to climate and canopy nitrogen in U.S. forests
}

\author{
Rossella Guerrieri \\ University of New Hampshire, Durham \\ Lucie C. Lepine \\ University of New Hampshire, Durham, lucie.lepine@unh.edu \\ Heidi Asbjornsen \\ University of New Hampshire, Durham, heidi.asbjornsen@unh.edu \\ Jingfeng Xiao \\ University of New Hampshire, Durham, j.xiao@unh.edu \\ Scott V. Ollinger \\ University of New Hampshire, Durham, scott.ollinger@unh.edu
}

Follow this and additional works at: https://scholars.unh.edu/ersc

Comments

This is an article published by AGU in Journal of Geophysical Research: Biogeosciences in 2016, available online:

https://dx.doi.org/10.1002/2016JG003415

\section{Recommended Citation}

Guerrieri, R., Lepine, L., Asbjornsen, H., Xiao, J., Ollinger, S.V. (2016). Evapotranspiration and water use efficiency in relation to climate and canopy nitrogen in U.S. forests. Journal of Geophysical Research: Biogeosciences, 121, 2610-2629, https://dx.doi.org/10.1002/2016JG003415.

This Article is brought to you for free and open access by the Institute for the Study of Earth, Oceans, and Space (EOS) at University of New Hampshire Scholars' Repository. It has been accepted for inclusion in Earth Systems Research Center by an authorized administrator of University of New Hampshire Scholars' Repository. For more information, please contact Scholarly.Communication@unh.edu. 


\section{Journal of Geophysical Research: Biogeosciences}

\author{
RESEARCH ARTICLE \\ 10.1002/2016JG003415 \\ Key Points: \\ - ET and WUE scaled with canopy N \\ with important implication on \\ vegetation-climate interactions \\ - Carbon isotope-derived ci/ca reconcile \\ leaf and ecosystem carbon uptake \\ - Combining foliar isotopes and tree \\ functional traits allowed to link leaf \\ and canopy water-carbon relations
}

Supporting Information:

- Supporting Information S1

Correspondence to:

R. Guerrieri,

rossellaguerrieri@gmail.com

Citation:

Guerrieri, R., L. Lepine, H. Asbjornsen, J. Xiao, and S. V. Ollinger (2016), Evapotranspiration and water use efficiency in relation to climate and canopy nitrogen in U.S. forests,

J. Geophys. Res. Biogeosci., 121,

2610-2629, doi:10.1002/2016JG003415

Received 16 MAR 2016

Accepted 20 SEP 2016

Accepted article online 23 SEP 2016

Published online 17 OCT 2016

C2016. American Geophysical Union. All Rights Reserved.

\section{Evapotranspiration and water use efficiency in relation to climate and canopy nitrogen in U.S. forests}

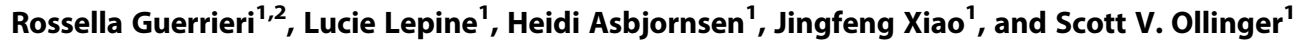 \\ ${ }^{1}$ Earth Systems Research Center, University of New Hampshire, Durham, New Hampshire, USA, ${ }^{2}$ Centre for Ecological \\ Research and Forestry Applications (CREAF), Universidad Autonoma de Barcelona, Cerdanyola, Barcelona, Spain
}

\section{Introduction}

Terrestrial ecosystems influence climate through regulation of carbon $(\mathrm{C})$, water $\left(\mathrm{H}_{2} \mathrm{O}\right)$, and energy exchanges with the atmosphere [Bonan, 2008; Canadell et al., 2007; Meir et al., 2006; Schulze, 2006]. In recent decades, advances in our understanding of the $C$ cycle include improved estimates of $C$ assimilation and storage [e.g., Pan et al., 2011], new methods for assessing spatiotemporal dynamics [Anav et al., 2015; Xiao et al., 2013, 2014], and better understanding of underlying environmental drivers [Fernández-Martínez et al., 2014a, 2014b; Heimann and Reichstein, 2008; Luyssaert et al., 2007; Reichstein et al., 2007]. Despite this progress, our understanding of how the $\mathrm{C}$ cycle interacts with the water $\left(\mathrm{H}_{2} \mathrm{O}\right)$ cycle has lagged. This is important because $\mathrm{CO}_{2}$ uptake by tree canopies occurs at the expense of $\mathrm{H}_{2} \mathrm{O}$ lost during transpiration, which has significant effects on heat partitioning and energy exchange between vegetation and the atmosphere [Bonan, 2008].

To date, most studies on the spatial patterns of evapotranspiration (ET) have focused on physical factors such as temperature, soil moisture, and vapor pressure deficit [Federer et al., 1996; Pan et al., 2015; Tang et al., 2006]. The extent to which biological factors, particularly plant nutrient status, affect ET has received less attention beyond results obtained using models [e.g., Dickinson et al., 2002; Lee et al., 2013]. In addition to $\mathrm{C}$ and $\mathrm{H}_{2} \mathrm{O}$ fluxes, biological properties of vegetation (e.g., canopy \%N and leaf area index (LAI)) can affect albedo, i.e., the fraction of the solar radiation not absorbed in the biosphere and reflected back to space [Ollinger et al., 2008; Zhu and Zeng, 2015]. Ollinger et al. [2008] observed positive correlations between canopy $\% \mathrm{~N}, \mathrm{C}$ assimilation, and albedo, raising the question of whether canopy $\mathrm{N}$ can influence climate by modulating radiative forcing as well as $\mathrm{C}$ assimilation. Furthermore, forest canopy ET can also modify the climate system by affecting albedo (i.e., through cloud formation), as well as the concentration of water vapor (a potent greenhouse gas) in the atmosphere [Bright et al., 2015]. Although intriguing, the net effect of these relationships on climate is difficult to ascertain without additional information on the nature of coupled $\mathrm{C}-\mathrm{N}-\mathrm{H}_{2} \mathrm{O}$ fluxes in forests. 
Water use efficiency (WUE), the $\mathrm{C}$ gain per unit of $\mathrm{H}_{2} \mathrm{O}$ loss through transpiration, is a key physiological parameter linking $\mathrm{C}$ and $\mathrm{H}_{2} \mathrm{O}$ cycles. Its definition and quantification vary depending on the scale of investigation (leaf, ecosystem, region, or globe), the time resolution (seconds, seasons, and years), and the measurement methods used. At the scale of individual leaves, WUE can be defined as (1) the ratio between net $\mathrm{CO}_{2}$ assimilation $(A)$ and stomatal conductance to $\mathrm{H}_{2} \mathrm{O}\left(g_{s}\right)$, known as intrinsic water use efficiency (iWUE), or (2) the ratio between $A$ and transpiration (E), known as instantaneous WUE [Farquhar et al., 1989; Donovan and Ehleringer, 1994]. One of the most commonly used methods for assessing tree-level iWUE is the measure of the stable carbon isotope composition $\left(\delta^{13} \mathrm{C}\right)$ in plant tissue. This approach is based on the well-established theory for the physiology of $\mathrm{C}_{3}$ photosynthesis, in particular, the relationship between the ratio of the $\mathrm{CO}_{2}$ in the intercellular spaces, $c_{i}$ and that in the atmosphere, $c_{a}$ (i.e., $c_{i} / c_{a}$ ), and $C$ isotope discrimination, $\Delta{ }^{13} C$ [Farquhar et al., 1982]. In addition to $\delta^{13} \mathrm{C}$, the measure of $\delta^{18} \mathrm{O}$ allows to gain additional insight into the ecophysiological processes underlying changes in leaf WUE [Scheidegger et al., 2000]. The $\delta^{18} \mathrm{O}$ in plant organic matter reflects the $\delta^{18} \mathrm{O}$ of leaf water where it was formed [Gessler et al., 2013], which, in turn, is affected by the $\delta^{18} \mathrm{O}$ of the water source [Craig and Gordon, 1965; Dongmann et al., 1974] and isotopic fractionations occurring during transpiration, as determined primarily by $g_{s}$. Notably, unenriched water from the soil and enriched water at the leaf evaporative sites continuously mix, as a function of transpiration rate and the pathway of water movement through foliar tissues (i.e., Péclet effect, see among others [Barbour et al., 2004; Barbour, 2007; Farquhar and Lloyd, 1993; Gessler et al., 2014; Roden et al., 2015; Song et al., 2013]). Several authors have reported a negative relationship between $\delta^{18} \mathrm{O}$ in leaf organic matter and $g_{s}$ due to their reciprocal link to relative humidity [Barbour et al., 2000, 2004; Grams et al., 2007; Moreno-Gutiérrez et al., 2012; Ripullone et al., 2009; Roden and Siegwolf, 2012; Sullivan and Welker, 2007]. The combination of the two isotopes in a conceptual model proposed by Scheidegger et al. [2000] has been successful applied to disentangle physiological mechanisms of tree species in response to environmental changes under natural [Barnard et al., 2012; Keitel et al., 2003; Moreno-Gutiérrez et al., 2012; Sullivan and Welker, 2007] and experimental conditions [Grams et al., 2007; Guerrieri et al., 2011; Leonelli et al., 2012; Jennings et al., 2016; Siegwolf et al., 2001].

At the scale of whole ecosystems, $\mathrm{C}$ and $\mathrm{H}_{2} \mathrm{O}$ fluxes have increasingly been assessed using the eddy covariance (EC) technique, which provides direct measurements of net ecosystem exchange (NEE) of $\mathrm{CO}_{2}$ between ecosystems and the atmosphere [Baldocchi, 2008]. NEE is routinely partitioned into its two components: gross primary production (GPP) and ecosystem respiration [Baldocchi et al., 2001; Reichstein et al., 2005]. The EC method also provides information related to energy fluxes, including incoming solar radiation $\left(R_{g}\right)$ and energy dissipation by sensible heat and latent heat (LE); the latter of which is used to estimate ET. Hence, ecosystem water use efficiency, WUE $_{e}$, is then obtained as the ratio between GPP and ET [Law et al., 2002; Beer et al., 2009; Keenan et al., 2013].

Although the approach of integrating tree-scale (e.g., using leaf or tree ring $\delta^{13} \mathrm{C}$ ) and ecosystem-scale (e.g., based on EC data) measurements to assess WUE is not new, most studies to date have focused on within-site comparisons of the methods applied to forests [Belmecheri et al., 2014; Michelot et al., 2011; Monson et al., 2010; Scartazza et al., 2014] or grasslands [Flanagan and Farquhar, 2014; Niu et al., 2011]. Analyses that compare both methods across a range of sites and broad climate and $\mathrm{N}$ gradients are less common. Furthermore, the combination of $\delta^{13} \mathrm{C}$ and $\delta^{18} \mathrm{O}$ in a dual-isotope conceptual model has proved to be useful to assess differences in co-occurring tree species in their water use strategies under different environmental conditions [e.g., Moreno-Gutiérrez et al., 2012; Lévesque et al., 2014], but to our knowledge its use to gain a better understanding of the ecosystem fluxes has never been explored. Cross-site comparisons that integrate EC and both stable carbon and oxygen isotopes data can offer a useful approach for advancing fundamental understanding of the spatial and temporal patterns of ecosystem fluxes.

The goal of this study was to explore the relationships among GPP, ET, WUE, and canopy \%N for Ameriflux sites that span a broad range of climate conditions, forest types, and tree species in the U.S. Given the different methodological approaches and associated scales over which WUE can be assessed, we also sought to determine whether isotopically based tree-level measurements are representative of EC-derived ecosystem-scale estimates. Finally, the differences among the investigated species in term of foliar \%N, wood anatomy (coniferous, ring porous, and diffuse porous type), and hydraulic strategies (isohydric and anisohydric) gave us the unique opportunity to test whether (i) the estimate of changes in $A$ and $g_{s}$ from the dualisotope approach could be improved by integrated species' functional traits and (ii) convergence and 


\section{AGU Journal of Geophysical Research: Biogeosciences 10.1002/2016JG003415}
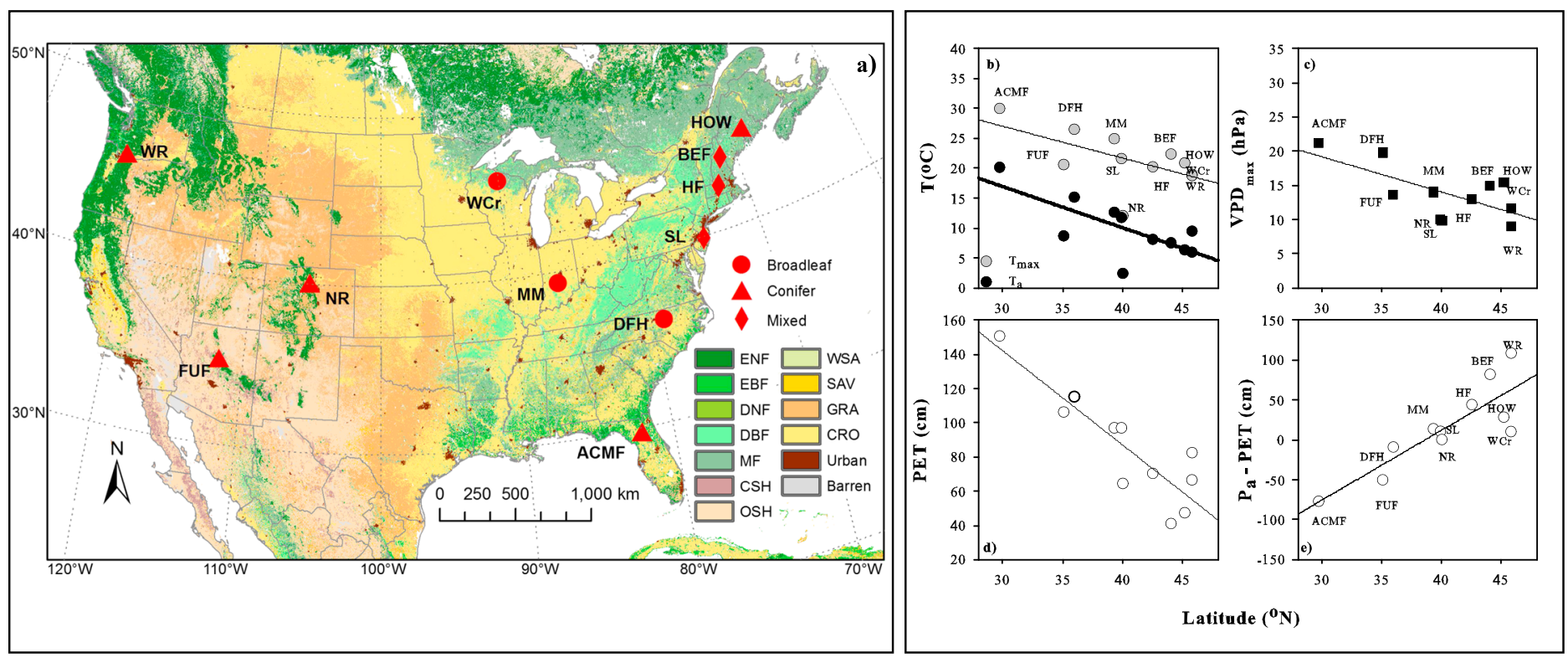

Figure 1. (a) Location of forested Ameriflux sites included in this study. The base map is the $1 \mathrm{~km}$ resolution land cover map derived from MODIS, and the vegetation types are evergreen needleleaf forests (ENF), evergreen broadleaf forests (EBF), deciduous needleleaf forests (DNF), deciduous broadleaf forests (DBF), mixed forests (MF), closed shrublands (CSH), open shrublands (OSH), woody savannas (WSA), savannas (SAV), grasslands (GRA), and croplands (CRO). (b-e) Relationship between environmental parameters and latitude. Parameters considered were mean annual temperature, $T_{a}\left(R^{2}=0.52, \beta=-0.69, p<0.05\right)$, and mean of the maximum temperature $\left(R^{2}=0.34, \beta=-0.53, p=0.05\right)$ when daily solar radiation, $R_{g}$, peaked (i.e., values $>800-1000 \mathrm{Wm}^{-2}$; Figure $2 \mathrm{~b}$ ), mean of maximum values of VPD $\left(\beta=-0.51, R^{2}=0.45, p<0.05\right.$; Figure $2 \mathrm{c}$ ), potential evapotranspiration (Figure $2 \mathrm{~d}$ ), PET $\left(R^{2}=0.77, \beta=-5.50, p<0.001\right.$ ), and difference between annual precipitation $\left(P_{a}\right)$ and PET as a proxy of moisture stress $\left(R^{2}=0.72, \beta=8.75, p<0.001\right.$; Figure 2e). $P_{a}$-PET values near or below zero (i.e., ACMF, FUF, DFH, and NR) indicate xeric conditions. For full name of the sites refer to Table 1.

divergence in functional traits facilitate a better understanding on ecosystem fluxes. To accomplish this, built on previous data (e.g., canopy $\% \mathrm{~N}$ ) from Ollinger et al. [2008], we added new data, i.e., foliar $\delta^{13} \mathrm{C}, \delta^{18} \mathrm{O}$, and \%N; conducted new analyses of eddy covariance data; and added three xeric sites in order to (1) extend the range of site moisture status, (2) examine the relationship between ET and WUE versus canopy N (which was not addressed in the previous work), and (3) explore species-specific physiological mechanisms for the dominant species at each site. We addressed the following specific questions: (1) do ET and WUE vary with forest canopy $\% \mathrm{~N}$, and if so, do these patterns amplify or offset the expected effects of $\mathrm{N}$ on climate via its influence on GPP alone? (2) Can leaf level measures of WUE be scaled to provide qualitative understanding of ecosystem-scale WUE and fluxes? And finally, (3) does incorporating information about species' functional traits when applying conceptual models to interpret leaf-level $\delta^{13} \mathrm{C}$ and $\delta^{18} \mathrm{O}$ in terms of $A$ and $g_{s}$ improve our understanding of the ecosystem $\mathrm{C}$ and $\mathrm{H}_{2} \mathrm{O}$ fluxes?

\section{Materials and Methods}

\subsection{Site Description and Foliar Sample Collection}

Eleven forested research sites within the AmeriFlux network were selected to represent major temperate forest types of North America (Figure 1a and Table 1) and to span a range of biological properties, i.e., $\mathrm{N}$ plant status, LAl, and biodiversity (assessed through Shannon diversity index, SH). Nine of the 11 sites were part of a previous study [Ollinger et al., 2008], so to make use of relevant data (i.e., canopy $\% \mathrm{~N}$ ) and samples already available. Moreover, other two sites were added to expand the range of biological and meteorological properties, with particular reference to water stress.

At each site, 6-12 plots were selected from within a $1 \mathrm{~km}$ radius around the flux tower that generally captured the species composition and soil conditions across the landscape. Where possible, we selected plots that were part of established research plot networks, where stem maps, tree counts, and other ancillary data were available. Within each plot, all dominant and codominant species were identified, and between two and five trees per species were selected for green leaf collection via shotgun sampling from several heights in the canopy as described in Ollinger and Smith [2005]. A camera-based point quadrat method [Smith and 


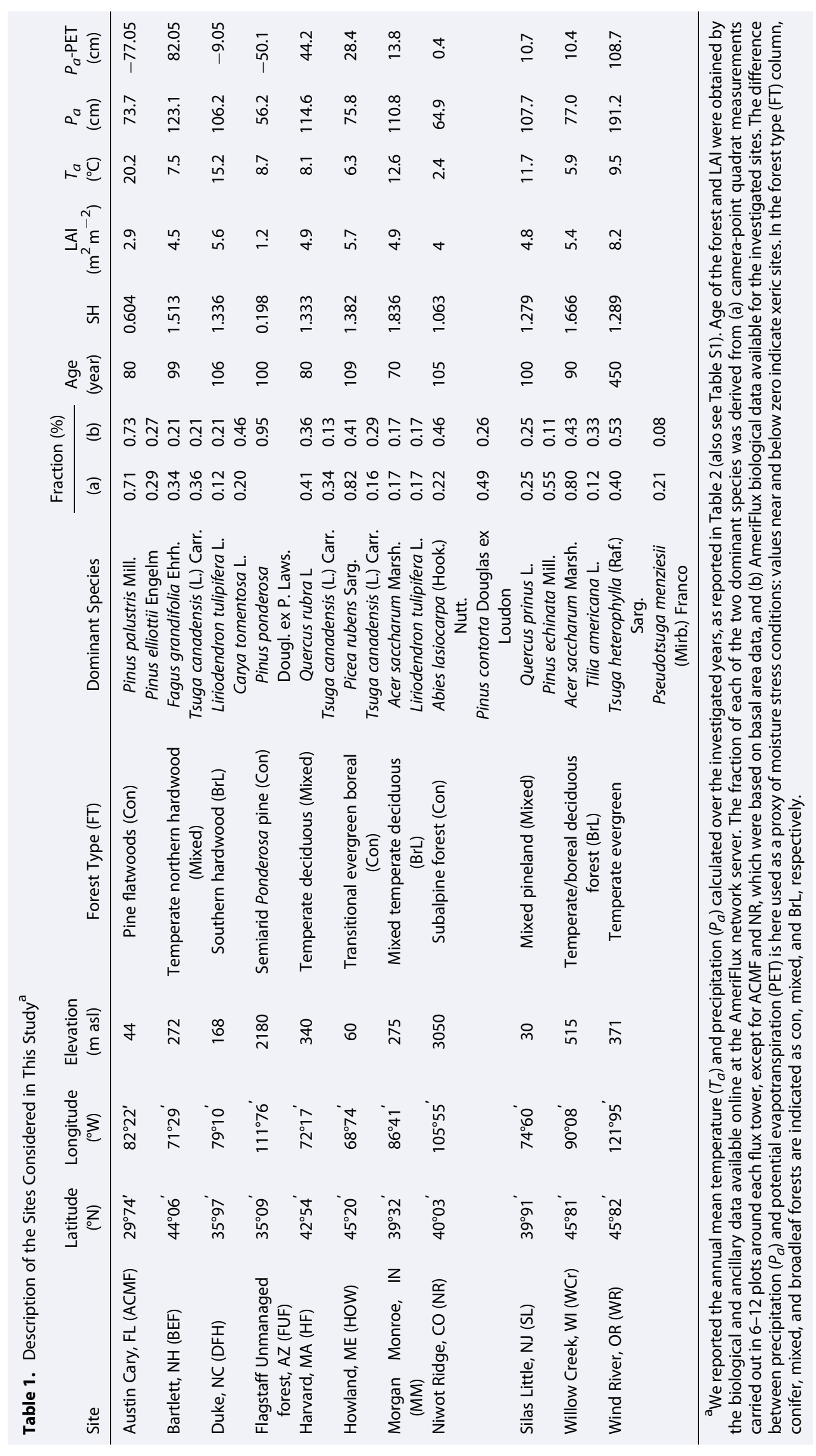


Martin, 2001] was used to determine the contribution of each species to the total canopy mass to derive species-weighted, plot-level whole canopy $\mathrm{N}$ concentration (as described in section 2.2.2). Foliar samples for analysis of $\% \mathrm{~N}$ and stable isotopes were obtained from the middle and upper canopies of 5 to 10 of the 2 most dominant tree species within the tower footprint $(\sim 500 \mathrm{~m})$ using the same method as described above. Sampling took place between 2002 and 2006 for nine sites as described in Ollinger et al. [2008] and between 2013 and 2014 for the remaining two sites and four of the previously sampled sites (Table S1 in the supporting information).

\subsection{Ecosystem-Level Data}

2.2.1. Carbon and Water Fluxes and Micrometeorological Data

We compiled flux and micrometeorological observations from each of the 11 EC flux sites (Figure 1a and Table 1). We considered half-hourly, level 4 standardized fluxes, i.e., GPP and ET, the former gap filled with the artificial neural network method [Moffat et al., 2007], and micrometeorological data (temperature [T], vapor pressure deficit $[\mathrm{VPD}]$, annual precipitation $\left[P_{a}\right]$, and incoming global radiation $\left.\left[R_{g}\right]\right)$. We considered years where L4 data were available at most of the sites, i.e., 2001-2004, with the exceptions of BEF, FUF, and SL (Table S1). Data were acquired from the AmeriFlux data archive (http://ameriflux.ornl.gov/) or from site investigators (i.e., at SL and FUF).

Half-hourly data were aggregated to daily values (08:00 A.M. to 04:00 P.M.) for the calculation of growing season (May-August) GPP $\left(\mathrm{g} \mathrm{C} \mathrm{m}^{-2} \mathrm{grs}^{-1}\right)$ and ET $\left(\mathrm{kg} \mathrm{H}_{2} \mathrm{O} \mathrm{m}^{-2} \mathrm{grs}^{-1}\right)$. For the same time window we calculated the averages of micrometeorological parameters: $T\left(T_{\text {grs }}\right), \mathrm{VPD}\left(\mathrm{VPD}_{\mathrm{grs}}\right), R_{g}\left(R_{\text {ggrs }}\right)$, and precipitation $\left(P_{\text {grs }}\right)$. We only considered fluxes obtained during dry canopy conditions, i.e., with no precipitation event, to avoid error introduced from canopy evaporation after a precipitation event [Beer et al., 2009; Keenan et al., 2013]. WUE was calculated as the ratio between GPP and ET:

$$
\mathrm{WUE}_{\mathrm{e}}=\frac{\mathrm{GPP}}{\mathrm{ET}}
$$

We also determined the rain use efficiency (RUE) as the ratio between GPP and $P_{a}$ :

$$
\mathrm{RUE}=\frac{\mathrm{GPP}}{P_{a}}
$$

Micrometeorological data were filtered to obtain the daily maximum values of VPD and $T$, by considering the time window between 11:00 A.M. and 02:00 P.M., where $R_{g}$ was higher than 800-1000 Wm ${ }^{-2}$ depending on the sites. The maximum $R_{g}\left(R_{\text {gmax }}\right)$ was assessed using the daily trend of $R_{g}$ over the years included in the study.

Finally, we used potential evapotranspiration (PET) and the difference between $P_{a}$ and PET to identify xeric and mesic sites. In this study we used the PET values as derived from the water balance model and available online (http://eos-earthdata.sr.unh.edu/data/data20.jsp). The model simulates soil moisture variations, evapotranspiration, and runoff on single-grid cells using biophysical data sets that include climatic drivers, vegetation, and soil properties and it derives PET by using the Penman-Monteith method.

With the exception of $P_{a}$, the cross-site climate gradient was well defined in terms of $T_{a}$ and $T_{\max }, \mathrm{VPD}_{\max }$ $R_{\text {ggrs, }}$ and $R_{\text {gmax }}$ (Figure $1 \mathrm{~b}$ ). PET decreased with increasing latitude, while the difference between annual $P_{a}$ and PET decreased, with values near or below zero (i.e., ACMF, FUF, DFH, and NR sites), indicating xeric conditions (Figure 1b).

\subsubsection{Canopy $\mathbf{N}$ Concentration}

Oven-dried and ground foliage was scanned on a benchtop visible and near-infrared spectrophotometer (Foss NIRSystems 6500) to determine foliar \%N according to methods described by Bolster et al. [1996]. Plot-level whole canopy $\% \mathrm{~N}$ (g N per $100 \mathrm{~g}$ foliar biomass) was calculated as the mean of foliar $\mathrm{N}$ concentrations for individual species in each plot, weighted by the fraction of canopy foliar mass per species [e.g., Smith et al., 2002]. This was determined by combining proportional leaf area from the camera-point quadrat observations with leaf mass per area measurements (see Smith and Martin [2001] for description of methods).

For comparison to $\mathrm{WUE}_{\mathrm{e}}$, estimates of foliar $\% \mathrm{~N}$ were obtained for a $500 \mathrm{~m}$ area roughly representative of the tower footprint, as reported in Ollinger et al. [2008]. These estimates were derived from NASA's Airborne 
Visible/Infrared Imaging Spectrometer and EO-1 Hyperion imagery as part of several previous investigations [Martin et al., 2008; Ollinger et al., 2008]. Exceptions included SL and FUF, which were not part of the previous studies and where cloud-free remotely sensed imagery was not available for the time period during which foliage was collected. For these sites, we assumed that the average of all plot-level canopy \%N we measured around the flux tower generally represented the range of canopy $\% \mathrm{~N}$ within the flux tower footprint and hence the ecosystem conditions captured by the flux tower data. This assumption could introduce error in ecosystem-scale \%N estimates, but this error should be small given the relatively homogenous canopies at these two sites.

Uncertainty could arise from the remotely sensed estimates of foliar $\% \mathrm{~N}$, which stem from prediction error in the calibration models (which is generally within $10-20 \%$ of the mean) and spatial heterogeneity in the flux tower footprints. These have been treated in detail in previous papers [Martin et al., 2008; Ollinger et al., 2008; Lepine et al., 2016]. However, we observed good agreement between foliar \%N (determined from elemental analysis) for the two dominant species at each site and both plot-level (whole canopy) $\% \mathrm{~N}$ derived from the camera-point quadrat method and remotely sensed canopy $\% \mathrm{~N}$, with most of the values close to the 1:1 line (Figure S1 in the supporting information). This gives gave us confidence that leaf- and tree-level foliar $\% \mathrm{~N}$ for the two dominant species are generally representative of the $\mathrm{N}$ status of the site.

2.2.3. Diversity Index and Leaf Area Index

Tree species diversity at each site was measured with Shannon's diversity index (SH),

$$
H=\sum_{i=1}^{s} p i \ln p i
$$

where $s$ is the number of species observed at the site and $p$ is the proportion of the ith species to the total canopy mass or stand basal area, as calculated from the canopy point-quadrat sampling or forest stem map data, respectively. LAI was obtained from the Biological and Ancillary data file available online for each of the AmeriFlux sites considered.

\subsection{Tree-Level Measurements}

\subsubsection{Stable $\mathbf{C}$ and $\mathbf{O}$ Isotopic Compositions and Foliar $\mathbf{N}$ Concentration}

Foliar samples collected from 5 to 10 trees of two dominant species at each site were oven dried at $70^{\circ} \mathrm{C}$ and then ground to a fine powder. An amount of $2-2.5 \mathrm{mg}$ of the sample was weighed in tin capsules and converted to $\mathrm{CO}_{2}$ and $\mathrm{N}_{2}$ with an elemental analyzer (ECS 4010, Costech Analytical, Valencia, CA) coupled to a continuous flow isotope ratio mass spectrometer (Delta PlusXP, ThermoFinnigan, Breman, Germany) to determine $\delta^{13} \mathrm{C}, \delta^{15} \mathrm{~N}$, and \%N. An additional $0.3-0.5 \mathrm{mg}$ of each sample was weighed in silver capsules, converted to CO with a pyrolysis elemental analyzer (TC/EA, ThermoFinnigan, Breman, Germany), and analyzed for $\delta^{18} \mathrm{O}$ with a continuous flow isotope ratio mass spectrometer (Delta PlusXP, Thermofinnigan, Breman, Germany). Carbon and oxygen isotope ratios were expressed in per mil (\%o) relative to the Vienna Peedee belemnite and Vienna SMOW international standard, respectively. The 2 sigma uncertainties of the isotope results were $0.5 \%$ and $0.4 \%$ for $\delta^{13} \mathrm{C}$ and $\delta^{18} \mathrm{O}$, respectively. All isotope analyses were carried out at the Stable Isotope Core Laboratory (Washington State University, USA).

\subsubsection{Determination of Leaf WUE}

iWUE was derived from $\delta^{13} \mathrm{C}$, based on the well-established theory linking leaf $c_{i} / c_{a}$ with $\Delta^{13} \mathrm{C}$ [Farquhar et al., 1982, 1989]:

$$
\Delta^{13} \mathrm{C}=\frac{\delta^{13} C_{\mathrm{a}}-\delta^{13} C_{\mathrm{p}}}{1+\delta^{13} C_{\mathrm{p}}}=a+(b-a) \frac{C_{i}}{C_{a}}
$$

where $\delta^{13} \mathrm{C}_{\mathrm{a}}$ is the carbon isotope composition of atmospheric $\mathrm{CO}_{2}, \delta^{13} \mathrm{C}_{\mathrm{p}}$ is the carbon isotope composition of plant tissue, $a$ is the isotope fractionation during $\mathrm{CO}_{2}$ diffusion (4.4\%), and $b$ is the isotope fractionation during fixation by Rubisco (27\%). Atmospheric $\mathrm{CO}_{2}$ concentrations and $\delta^{13} \mathrm{C}$ were obtained from Mauna Loa records (http://www.esrl.noaa.gov/gmd/dv/ftpdata.html). iWUE ( $\mu \mathrm{mol} \mathrm{CO}_{2} \mathrm{~mol}^{-1} \mathrm{H}_{2} \mathrm{O}$ ) was then calculated using the following equation:

$$
\text { iWUE }=\frac{A}{g_{s}}=\frac{c_{a}-c_{i}}{1.6}=\frac{c_{a}}{1.6}\left(\frac{b-\Delta^{13} C}{b-a}\right)
$$


where 1.6 is the molar diffusivity ratio of $\mathrm{CO}_{2}$ to $\mathrm{H}_{2} \mathrm{O}$ (i.e., $g_{\mathrm{CO} 2}=g_{\mathrm{H} 2 \mathrm{O}} / 1.6$ ). The iWUE as derived from equation (5) assumes VPD to be $1 \mathrm{~mol} \mathrm{~mol}^{-1}$. We also derived the instantaneous WUE, i.e., $A / E$ ( $\mu \mathrm{mol} \mathrm{CO} \mathrm{mol}^{-1} \mathrm{H}_{2} \mathrm{O}$ ), by using the following equation and given that $E=g_{s} \times \mathrm{VPD}$ [Farquhar and Sharkey, 1982]:

$$
\mathrm{WUE}=\frac{A}{E}=c_{a}\left(\frac{b-\Delta^{13} \mathrm{C}}{1.6 \mathrm{VPD}}\right)
$$

Both intrinsic and instantaneous WUEs were converted from $\mu \mathrm{mol} \mathrm{CO}_{2} \mathrm{~mol}^{-1} \mathrm{H}_{2} \mathrm{O}$ to $\mathrm{g} \mathrm{C} / \mathrm{kg} \mathrm{H} \mathrm{H}_{2} \mathrm{O}$ to better compare the leaf and ecosystem WUE. Henceforth, we will refer to intrinsic and instantaneous WUEs in converted units as $W U E_{\mathrm{vpd} 1}$ and $\mathrm{WUE}_{\mathrm{vpd}}$, respectively.

2.3.3. Combination of Foliar $\Delta^{13} \mathrm{C}$ and $\delta^{18} \mathrm{O}$ in a Dual-Isotope Conceptual Model

We combined the two isotopes in a conceptual model [Scheidegger et al., 2000] (and its further modification by Grams et al. [2007]) to examine the degree to which foliar WUE was influenced by $A$ versus $g_{s}$. An assumption of the dual-isotope model is that $\delta^{18} \mathrm{O}$ of atmospheric and soil water is similar for the two species, which is likely true for the two dominant species at each site. We used $\Delta{ }^{13} \mathrm{C}$ to derive changes in $c_{i} / c_{a}$ (cf. equation (4)) and $\delta^{18} \mathrm{O}$ to assess qualitative changes in $g_{s}$, assuming a negative relationship between $\delta^{18} \mathrm{O}$ and $g_{s}$ [Grams et al., 2007]. Here we modify the dual-isotope conceptual model by including tree species' functional traits related to $\mathrm{CO}_{2}$ uptake (foliar $\% \mathrm{~N}$ ) and transpiration (hydraulic strategies and wood anatomy).

Tree species have been classified in two main categories, according to the role of stomatal control on their strategy of water use: isohydric and anisohydric species [Tardieu and Simonneau, 1998; Martínez-Vilalta et al., 2014]. Isohydric species display a water-conserving strategy, with tight stomatal regulation to maintain stable leaf water potential. Conversely, anisohydric species have less strict stomatal control and exhibit a water-spending behavior, enabling them to maintain $C$ assimilation for longer periods of time under conditions of reduced water availability. Wood anatomical features significantly affect tree hydraulic conductivity and stomatal responsiveness. Indeed, previous studies reported isohydric behavior for conifer and diffuse porous species, while anisohydric for ring porous species [Carnicer et al., 2013; Meinzer et al., 2013].

Directional changes in $\Delta^{13} \mathrm{C}$ and $\delta^{18} \mathrm{O}$ for species $X$ (higher $\Delta^{13} \mathrm{C}$-higher $c_{i} / c_{a}$ ) versus species $Y$ (lower $\Delta^{13} \mathrm{C}$ lower $c_{i} / c_{a}$ ) were used to assess the most likely scenario explaining observed differences between the two species (if any) in terms of $A$ and/or $g_{s}$ after taking into account also differences between the two species in term of foliar \%N (which is directly linked to $A$ ) and hydraulic strategies and wood anatomy (supporting differences in $g_{s}$ ).

For conifer sites having codominant isohydric species, we hypothesized the two species to show differences in the $\Delta^{13} \mathrm{C}$ but not $\delta^{18} \mathrm{O}$, suggesting similar $g_{s}$ as supported by similar wood anatomy and hydraulic strategies. By contrast, for mixed forest sites having dominant species with diverging hydraulic strategies and wood anatomical features, we predict anisohydric (broadleaf) species to show greater variability in $\Delta^{13} \mathrm{C}$ and $\delta^{18} \mathrm{O}$, reflecting higher $g_{s}$ to sustain the higher $A$ (supported by the higher foliar $\% \mathrm{~N}$ ) compared to the more water-saving isohydric (conifer) species. Finally, for broadleaf forests we expect to find a similar scenario as mixed forests, despite the two species having similar wood anatomical features, mostly explained by the differences in foliar \%N between the two codominant species, which lead to difference in $A$.

\subsection{Statistical Analyses}

Analysis of variance and Tukey's multiple comparisons were used to examine differences in the mean values for fluxes and leaf/ecosystem WUE across the different sites. Independent sample $t$ tests were employed to test for differences between the two dominant species within each site for foliar $\% \mathrm{~N}, \Delta^{13} \mathrm{C}, \delta^{18} \mathrm{O}$, and $W_{U E} E_{\mathrm{vpd} 1}$. Pearson's correlation coefficients and simple regression analyses were used to examine the relationship between the leaf level (i.e., $\mathrm{WUE}_{\mathrm{vpd}}, \mathrm{WUE}_{\mathrm{vpd}}, \Delta^{13} \mathrm{C}, \delta^{18} \mathrm{O}$, and \%N) and ecosystem level (GPP, ET, $\mathrm{WUE}_{\mathrm{e}}$, and canopy $\% \mathrm{~N}$ ) parameters. Stepwise multiple regression analyses were used to assess which of the environmental (i.e., $T_{\text {grs }}, R_{\text {ggrs }}, P_{\text {grs }}, \mathrm{VPD}_{\text {grs }}, T_{\text {max }}, \mathrm{VPD}_{\text {max }}$ and $R_{\text {gmax }}$ ) and biological (i.e., LAl, canopy $\% \mathrm{~N}$, and $\mathrm{SH}$ ) variables accounted for most of the cross-site variation in forest fluxes. We started with the "saturated" model, which included all the predictors, and then we used the Akaike information criterion-based backward elimination to select the best model. We also calculated the variance inflation factor (VIF) to ensure that all the predictors in the final model had a VIF less than 4, indicating minimal multicollinearity. For WUE, 
Table 2. Mean ( $\pm \mathrm{SE})$ of GPP, ET, and $\mathrm{WUE}_{\mathrm{e}}$ Calculated over Multiple Years (see Table $\mathrm{S} 1$ ) at the $11 \mathrm{EC}$ Sites Across North America ${ }^{a}$

\begin{tabular}{|c|c|c|c|c|c|c|c|c|c|c|}
\hline \multirow{3}{*}{$\begin{array}{l}\text { Site } \\
\text { ACMF }\end{array}$} & \multicolumn{6}{|c|}{ Ecosystem WUE } & \multicolumn{4}{|c|}{ Leaf WUE } \\
\hline & \multicolumn{2}{|c|}{$\begin{array}{cr}\mathrm{GPP} & \mathrm{SE} \\
\left(\mathrm{gCm}^{-2} \mathrm{grs}^{-1}\right)\end{array}$} & \multicolumn{2}{|c|}{$\begin{array}{c}\mathrm{ET} \\
\left(\mathrm{kg} \mathrm{H}_{2} \mathrm{O} \mathrm{m}^{-2} \text { grs }^{-1}\right)\end{array}$} & \multicolumn{2}{|c|}{$\begin{array}{cc}\text { WUE }_{e} & \text { SE } \\
\left(\mathrm{g} \mathrm{C} / \mathrm{kg} \mathrm{H}_{2} \mathrm{O}\right)\end{array}$} & \multicolumn{2}{|c|}{$\begin{array}{l}\text { WUE }_{\text {vpd1 }} \quad \text { SE } \\
\qquad\left(\mathrm{g} \mathrm{C} / \mathrm{kg} \mathrm{H} \mathrm{H}_{2} \mathrm{O}\right)\end{array}$} & \multicolumn{2}{|c|}{$\begin{array}{cc}\text { WUE }_{\text {vpd }} & \text { SE } \\
\left(\mathrm{g} \mathrm{C} / \mathrm{kg} \mathrm{H} \mathrm{H}_{2} \mathrm{O}\right)\end{array}$} \\
\hline & $346.45 \mathrm{c}$ & 57.37 & $226.11 \mathrm{~b}$ & 8.64 & $1.57 \mathrm{~d}$ & 0.30 & $5.09 \mathrm{~cd}$ & 0.12 & $2.32 \mathrm{~d}$ & 0.07 \\
\hline $\mathrm{BEF}$ & $708.27 \mathrm{ab}$ & 28.68 & $206.27 \mathrm{~b}$ & 13.88 & $3.46 a b$ & 0.26 & $4.59 \mathrm{de}$ & 0.11 & $4.00 \mathrm{c}$ & 0.10 \\
\hline DFH & $848.93 \mathrm{a}$ & 14.74 & 333.52 a & 2.84 & $2.55 \mathrm{bc}$ & 0.03 & $4.38 \mathrm{cde}$ & 0.35 & $2.49 \mathrm{~d}$ & 0.20 \\
\hline FUF & $351.36 \mathrm{c}$ & 26.63 & $184.82 \mathrm{~b}$ & 8.66 & $1.90 \mathrm{~cd}$ & 0.11 & $7.30 \mathrm{a}$ & 0.12 & $3.67 c$ & 0.06 \\
\hline HF & 823.81 a & 61.39 & $226.60 \mathrm{~b}$ & 11.43 & $3.82 \mathrm{a}$ & 0.25 & $4.39 \mathrm{e}$ & 0.10 & $4.00 c$ & 0.10 \\
\hline HOW & $777.76 \mathrm{ab}$ & 20.54 & $202.90 \mathrm{~b}$ & 9.92 & $3.85 \mathrm{a}$ & 0.14 & $4.68 \mathrm{de}$ & 0.13 & $3.84 \mathrm{c}$ & 0.14 \\
\hline MM & $978.11 \mathrm{a}$ & 23.69 & $301.06 \mathrm{a}$ & 3.53 & $3.25 \mathrm{a}$ & 0.07 & $4.71 \mathrm{cde}$ & 0.21 & $3.51 \mathrm{c}$ & 0.16 \\
\hline NR & $407.43 \mathrm{C}$ & 13.94 & $226.02 \mathrm{~b}$ & 5.93 & $1.80 \mathrm{~d}$ & 0.05 & $6.09 \mathrm{~b}$ & 0.15 & $6.68 \mathrm{a}$ & 0.23 \\
\hline SL & $868.09 a b$ & & $209.61 \mathrm{~b}$ & & $4.13 \mathrm{a}$ & & 4.65 cde & 0.07 & $4.68 \mathrm{~b}$ & 0.07 \\
\hline WCr & 806.57 a & 38.29 & $230.72 b$ & 16.57 & $3.59 a$ & 0.32 & 5.46 bc & 0.18 & $6.24 a$ & 0.21 \\
\hline WR & $604.30 \mathrm{~b}$ & 43.34 & $152.39 \mathrm{~b}$ & 20.63 & $3.45 \mathrm{a}$ & 0.22 & $4.88 \mathrm{cde}$ & 0.23 & $2.41 \mathrm{c}$ & 0.11 \\
\hline
\end{tabular}

${ }^{\mathrm{a}}$ Mean ( $\pm \mathrm{SE}$ ) of leaf WUE as derived from $\delta^{13} \mathrm{C}$ measured in 5 to 10 trees of the two most dominant species as reported in the Table 1. The different letters indicate the significant differences among values, as tested with ANOVA and Tukey's post hoc test.

GPP, and ET, individual years were considered as replicates for each site, and hence, we included in the model the meteorological factors concurrent with measured fluxes (Table S1). The level of significance of all statistical tests was set as $p \leq 0.05$. R project statistical computing [R Core Team, 2014] was used for all the analyses.

\section{Results}

3.1. Spatial Variabilities of $\mathrm{C}$ and $\mathrm{H}_{2} \mathrm{O}$ Fluxes and Relationship with Biological and Environmental Factors

In Table 2 we summarize main values of $\mathrm{C}$ and $\mathrm{H}_{2} \mathrm{O}$ fluxes and $\mathrm{WUE}_{\mathrm{e}}$ calculated over multiple years for 11 AmeriFlux sites along a distinct environmental gradient, as described in Figure 1. We observed a high variability across sites in the case of GPP, with values ranging from $900-800 \mathrm{~g} \mathrm{C} \mathrm{m}^{-2} \mathrm{grs}^{-1}$ at the MM, WCr, DFH, and HF sites to $300 \mathrm{~g} \mathrm{C} \mathrm{m}^{-2} \mathrm{grs}^{-1}$ at the ACMF and FUF conifer-dominated forest sites. By contrast, changes in the ET were less pronounced among the different sites, with values ranging between 100 and $300 \mathrm{~kg} \mathrm{H}_{2} \mathrm{O} \mathrm{m}^{-2} \mathrm{grs}^{-1}$.

GPP $(F=30.4, p<0.001)$ and WUE $_{\mathrm{e}}(F=18.4, p<0.001)$ were significantly lower at the xeric sites (ACMF, FUF, and NR) than the mesic sites (Table 2). The highest ET values were found at the two broadleaf-dominated forests, MM and DFH, which also showed among the highest GPP values. The rest of the sites, including the more xeric ones, showed similar ET values (Table 2).

One of our goals was to assess whether $\mathrm{C}$ and $\mathrm{H}_{2} \mathrm{O}$ fluxes and their ratio were related to canopy \%N. Simple regression analyses revealed that both GPP and ET were positively correlated with canopy \%N $\left(R^{2}=0.65\right.$, $p<0.01$ for GPP and $R^{2}=0.40, p<0.05$ for ET; Figures $2 \mathrm{a}$ and $2 \mathrm{~b}$ ). Similarly, $\mathrm{WUE}_{\mathrm{e}}$ and rain use efficiency (RUE) increased with increasing canopy \%N (Figures $2 \mathrm{c}$ and $2 \mathrm{~d}$ ), although the relationship was significant only for RUE $\left(R^{2}=0.39, p<0.05\right)$.

Multiple regression analyses showed that the relationship between fluxes and canopy $\% \mathrm{~N}$ were still significant when other variables were taken into account. Both GPP and WUE $_{e}$ increased with latitude, while $\mathrm{ET}_{\text {grs }}$ decreased. GPP and $\mathrm{WUE}_{\mathrm{e}}$ were positively correlated with $T_{\text {grs }}$, while for $\mathrm{ET}$ we found a negative relationship with $T_{\text {grs }}$, although the slope coefficient was not significant (Table 3). When we used the maximum values of the environmental parameters in the statistical analysis, VPD $\max$ and $R_{g \max }$ were the only significant environmental variables for GPP and ET, respectively (Table 3). Of the biological factors included in the statistical model, $\mathrm{SH}$ and canopy $\% \mathrm{~N}$ were associated with both GPP and ET, showing a positive slope. GPP showed a significant relationship with LAI but only when including the maximum values for climate variables in the model (Table 3). Overall, the final models for GPP and $W_{U} E_{e}$ explained a high proportion of the variance, i.e., $>80$ and $70 \%$, respectively, while the final ET model only explained $48-49 \%$ of the variance. 

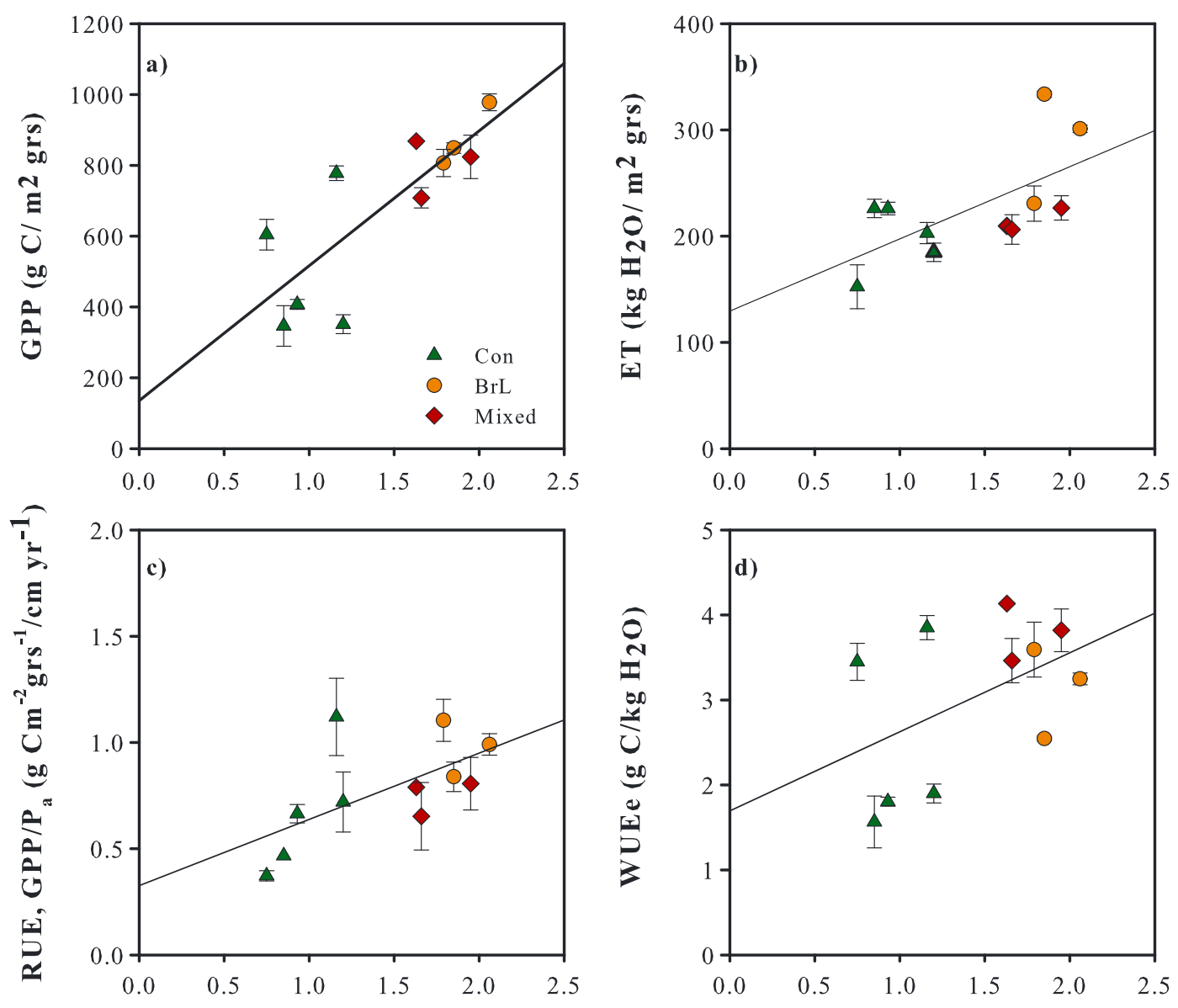

Canopy N (\%)

Figure 2. Relationship between (a) GPP $\left(y=135.5+380.9 x ; R^{2}=0.65, p<0.01\right)$, (b) $\mathrm{ET}\left(y=129.5+67.9 x ; R^{2}=0.40, p<0.05\right)$, (c) rain use efficiency (RUE) $\left(y=0.31+0.32 x ; R^{2}=0.39, p<0.05\right)$, and (d) WUE $\left(y=1.69+0.93 x ; R^{2}=0.23, p=0.13\right)$ versus remotely sensed derived (with the exception of SL and FUF, cf. main text) canopy \%N for 11 Ameriflux sites in the U.S.

We also explored patterns in WUE $_{\mathrm{e}}$ based on the correlation between GPP and ET. We found that GPP and ET were significantly correlated (Figure 3), with the slope of the relationship indicating the gram of carbon uptake per kilogram of water lost by ET.

\subsection{WUE at Leaf and Ecosystem Scales}

WUE differed significantly across sites (Table 2), but the nature and magnitude of these differences varied between leaf- and ecosystem-scale measurements. WUE $\mathrm{vpd}_{\mathrm{vp} 1}$ showed the highest values at two of the xeric sites, FUF and NR, followed by WCR, while the remaining sites showed similar values $(F=48.85, p<0.001$; Table 2). When considering $W_{U} E_{v p d}$, the sites clustered into three groups, with WCR and NR showing the highest WUE $E_{\mathrm{vpd}}$, while WR, ACMF, and DFH had the lowest; the remaining sites showed similar (intermediate) values $(F=100.9, p<0.001$; Table 2$)$.

WUE for the three northeastern sites (HOW, BEF, and HF) showed similar values $\left(\approx 4 \mathrm{~g} \mathrm{C} / \mathrm{kg} \mathrm{H} \mathrm{H}_{2} \mathrm{O}\right.$, regardless of the scale (leaf and ecosystem) or whether we took into account VPD in the leaf-level WUE calculation (Table 2). However, this was not the case for other sites, i.e., ACMF, FUF, NR, WCr, and WR, where values of leaf WUE were higher than those measured at the ecosystem scale (Table 2).

Leaf and ecosystem WUEs were significantly related to each other only in the case of WUE $\mathrm{vpd}_{1}$, with the two parameters showing a negative correlation (Figure S2). Furthermore, the leaf $c_{i} / c_{a}$ and $c_{i}$, as derived from $\delta^{13} C$, were both positively associated with ecosystem GPP (Figure S3). 


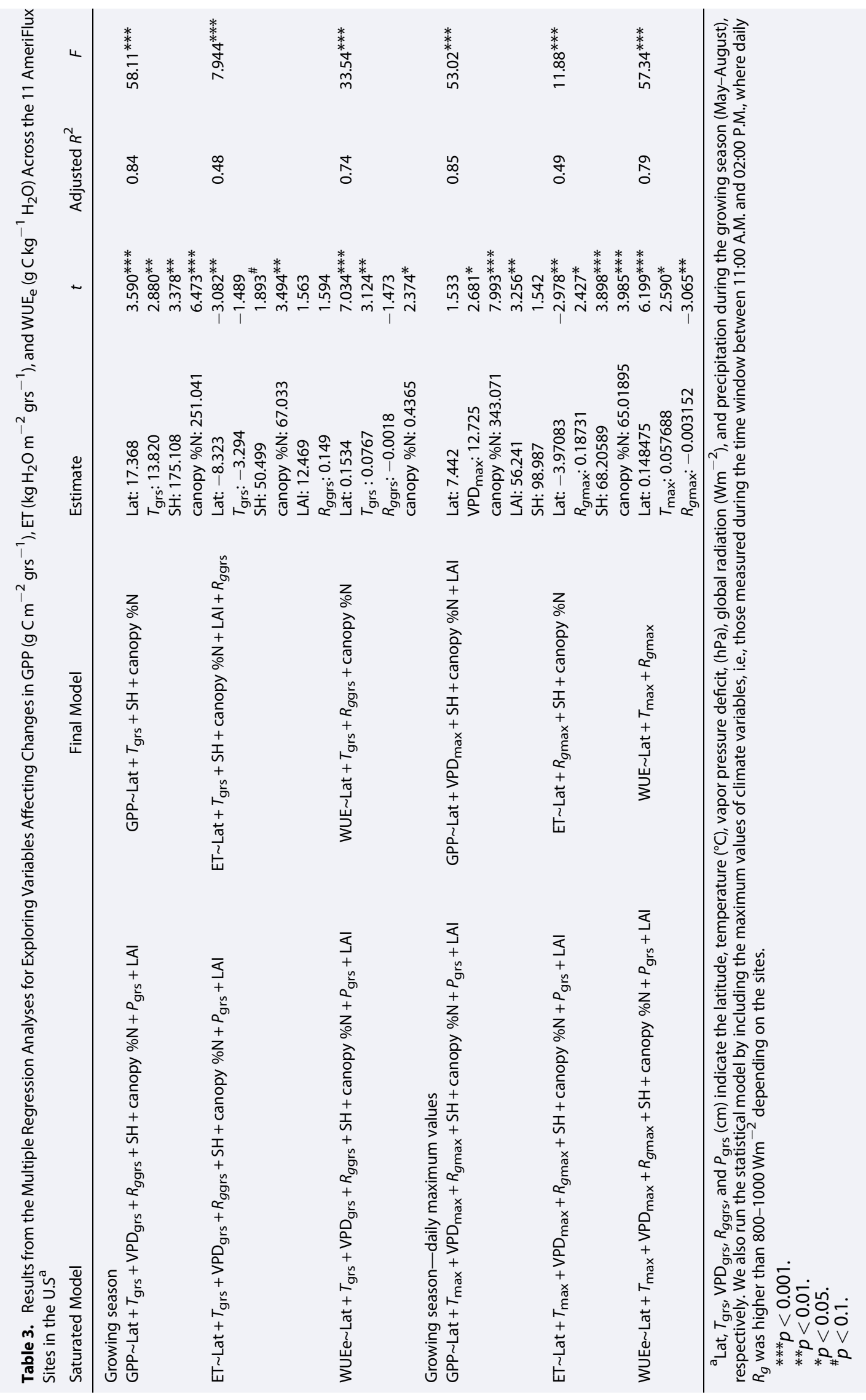




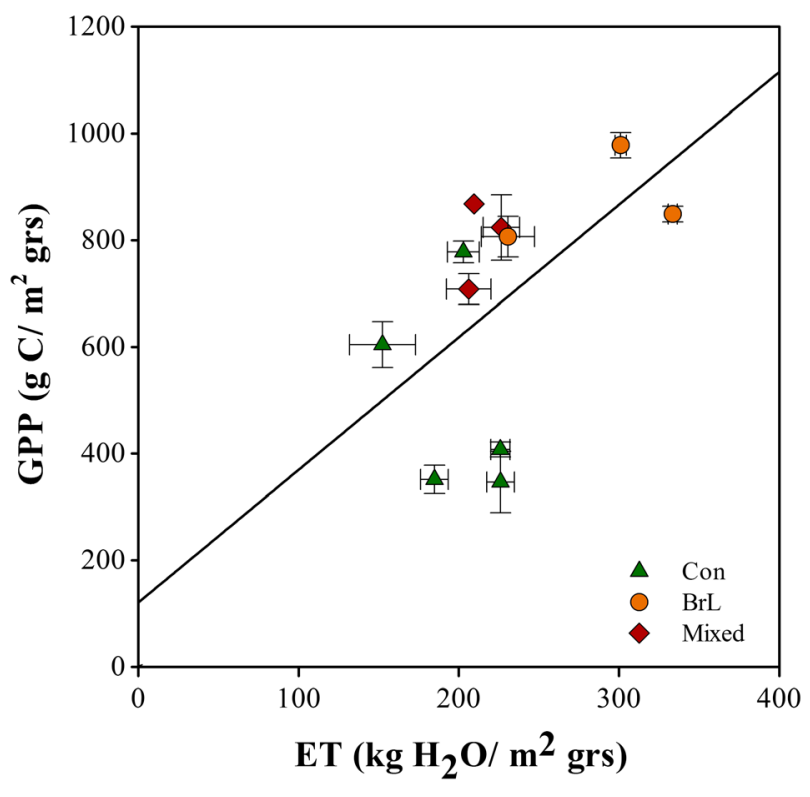

Figure 3. Relationship between GPP and ET across the study sites $\left(R=0.61 ; R^{2}=0.36, y=35.4+2.8 x, p<0.05\right)$. Each point represents the mean $( \pm \mathrm{SE})$ over multiple years of fluxes monitoring (Table S1).

As observed at the ecosystem scale, the slope of the relationship between $\mathrm{WUE}_{\mathrm{vpd} 1}$ and foliar $\% \mathrm{~N}$ was positive, although the relationship was not significant (Figure 4). We observed a clear distinction in the relationship between $\mathrm{WUE}_{\mathrm{vpd} 1}$ and foliar \%N among forest types (FT: conifer and mixed $+\mathrm{BrL}$ ), although the difference in the slope between FT was not significant. When we considered each site separately, the relationship between leaf $W_{U E} E_{v p d}$ and foliar $\% \mathrm{~N}$ within tree species was not consistent: $\mathrm{WUE}_{\mathrm{vpd} 1}$ was positively related to foliar $\% \mathrm{~N}$ in the case of $\mathrm{HF}$ $(\beta=0.66, p<0.01), \mathrm{MM}(\beta=2.1, p<0.05)$, and WCR $(\beta=0.89, p<0.05)$, while for HOW the relationship was negative $(\beta=-3.18, p<0.0001$; data not shown).

\subsection{Species-Specific Difference in Foliar $\Delta^{13} \mathrm{C}, \delta^{18} \mathrm{O}$, and $\% \mathrm{~N}$}

At most of the sites (with the exception of $\mathrm{NR}, \mathrm{WR}, \mathrm{BEF}$, and DFH), $\Delta^{13} \mathrm{C}$ and/or $\delta^{18} \mathrm{O}$ differed significantly across the two dominant species. With the exception of conifer-dominated forests, we observed differences in foliar $\% \mathrm{~N}$ between the two dominant species (Table 4).

Figure 5 describes the shifts in the two isotopes according to the dominant species' hydraulic strategies and wood anatomy features as described in Table S2. At the two conifer-dominated forests (Figure 5a), we found that the two isohydric species, i.e., Tsuga canadensis and Picea rubens at HOW and Pinus

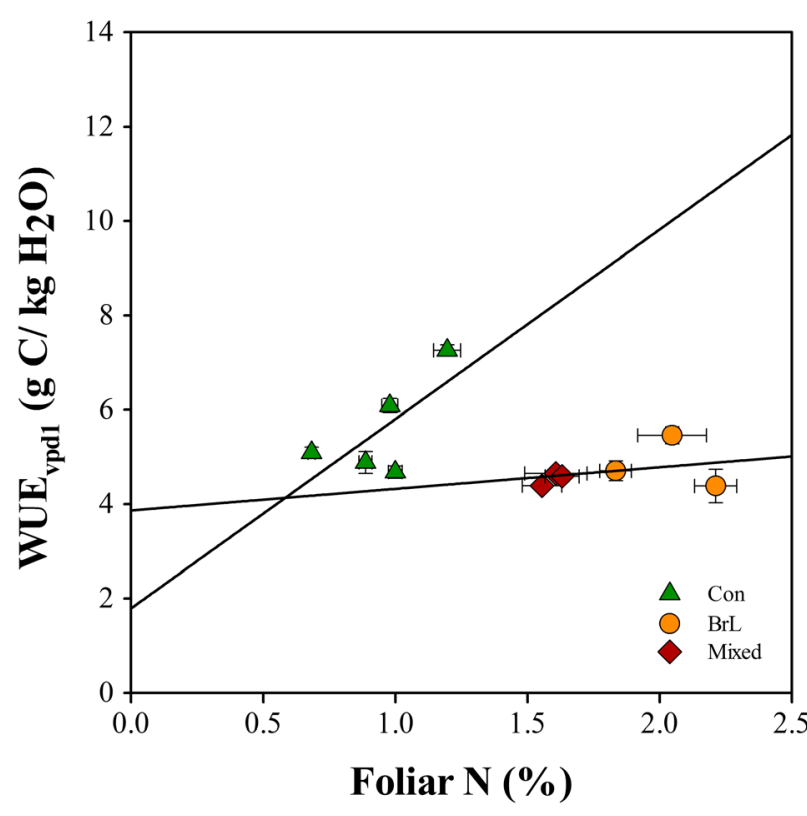

Figure 4. Relationship between $\mathrm{WUE}_{\mathrm{vpd} 1}$ and foliar $\% \mathrm{~N}$ for 11 forests in the U.S. Each point represents the mean $( \pm S E)$ of values obtained from 5 to 10 trees per species at each site. palustris and Pinus elliottii at ACMF, differed for $\Delta^{13} \mathrm{C}$ but not for $\delta^{18} \mathrm{O}$ and foliar $\% N$. Even though the two species at HOW showed different $\Delta^{13} \mathrm{C}$, we found similar values for $W_{U E} E_{\mathrm{vpd} 1}$, whereas at ACMF $P$. palustris had a significant higher WUE $_{\mathrm{vpd} 1}$ than $P$. elliottii. At broadleaf forests dominated by diffuse porous species (Figure 5b), Acer saccharum (isohydric) had a lower foliar $\% \mathrm{~N}$, higher $\Delta^{13} \mathrm{C}$ and $\delta^{18} \mathrm{O}$, but lower $\mathrm{WUE}_{\mathrm{vpd} 1}$ than the codominant species, Liriodendron tulipifera at MM and Tilia americana at WCr; both of them considered as intermediate isohydric (Table S2). Finally, in the case of the mixed forests (HF and SL), we found that the conifer species had a higher $\Delta^{13} \mathrm{C}$, lower foliar $\% \mathrm{~N}$, and lower WUE $\mathrm{vpd}_{1}$ than the broadleaf species (Figure $5 \mathrm{c}$ ). However, Pinus echinata had a lower $\delta^{18} \mathrm{O}$ than the Quercus prinus at SL, while in the case of HF the $T$. canadensis had a higher $\delta^{18} \mathrm{O}$ than the Quercus rubra. 


\begin{tabular}{|c|c|c|c|c|c|}
\hline Site & Species & $\Delta^{13} \mathrm{C}(\%)$ & $\delta^{18} \mathrm{O}(\% 0)$ & WUE $_{\mathrm{vpd} 1}\left(\mathrm{~g} \mathrm{C} / \mathrm{kg} \mathrm{H}_{2} \mathrm{O}\right)$ & $\% \mathrm{~N}$ \\
\hline \multirow[t]{2}{*}{ ACMF } & Pinus eliottii (piel) & $21.01(0.33)^{* *}$ & $25.74(0.33)$ & $4.48(0.24)^{* *}$ & $0.68(0.02)$ \\
\hline & Pinus palustris (pipa) & $19.72(0.57)$ & $25.56(0.82)$ & $5.40(0.09)$ & $0.68(0.08)$ \\
\hline \multirow[t]{2}{*}{ BEF } & Fagus grandifolia (fagr) & $20.68(0.20)$ & $26.45(0.23)$ & $4.74(0.14)$ & $* * *$ \\
\hline & Tsuga canadensis (tsca) & $21.14(0.22)$ & $26.62(0.10)$ & $4.42(0.16)$ & $1.26(0.04)$ \\
\hline \multirow[t]{2}{*}{ DFH } & Carya tomentosa (cato) & $20.23(0.53)$ & $29.40(0.60)$ & $4.09(0.81)$ & $1.98(0.08)^{* *}$ \\
\hline & Liriodendron tulipifera (litu) & $20.47(0.33)$ & $28.60(0.23)$ & $4.61(0.22)$ & $2.44(0.09)$ \\
\hline FUF & Pinus ponderosa (pipo) & $17.17(0.16)$ & $29.70(0.40)$ & $7.30(0.12)$ & $1.20(0.05)$ \\
\hline \multirow[t]{2}{*}{ HF } & Quercus rubra (quru) & $20.75(0.19)^{* * *}$ & $24.31(0.30)$ & $4.71(0.13)^{* * *}$ & $1.91(0.09)^{* *}$ \\
\hline & Tsuga canadensis (tsca) & $21.72(0.18)$ & $26.16(0.20)$ & $4.04(0.16)$ & $1.18(0.03)$ \\
\hline \multirow[t]{2}{*}{ HOW } & Picea rubens (piru) & $20.38(0.29)^{*}$ & $25.24(0.22)$ & $4.97(0.15)$ & $0.97(0.03)$ \\
\hline & Tsuga Canadensis (tsca) & $21.20(0.30)$ & $25.48(0.13)$ & $4.36(0.21)$ & $1.03(0.05)$ \\
\hline \multirow[t]{2}{*}{ MM } & Acer saccharum (acsa) & $20.99(0.44)^{*}$ & $29.04(0.35)^{*}$ & $4.33(0.30)^{*}$ & $1.70(0.06)^{* *}$ \\
\hline & Liriodendron tulipifera (litu) & $19.71(0.19)$ & $25.51(0.26)$ & $5.20(0.14)$ & $2.01(0.06)$ \\
\hline \multirow[t]{2}{*}{ NR } & Abies lasiocarpa (abla) & $18.74(0.34)$ & $26.18(0.36)$ & $5.83(0.14)$ & $1.00(0.04)$ \\
\hline & Pinus contorta (pico) & $18.06(0.24)$ & $25.64(0.45)$ & $6.29(0.17)$ & $0.96(0.04)$ \\
\hline \multirow[t]{2}{*}{ SL } & Pinus echinata (piec) & $21.04(0.11)^{* * *}$ & $23.11(0.17)^{*}$ & $4.46(0.08)^{* * *}$ & $1.26(0.15)^{*}$ \\
\hline & Quercus prinus (qupr) & $20.53(0.14)$ & $24.42(0.19)$ & $4.83(0.10)$ & $1.93(0.12)$ \\
\hline \multirow[t]{2}{*}{ WCr } & Acer saccharum (acsa) & $20.08(0.25)^{* * *}$ & $26.23(0.25)^{* * *}$ & $4.99(0.17)^{* * *}$ & $1.69(0.10)^{* * *}$ \\
\hline & Tilia americana (tiam) & $18.72(0.23)$ & $23.21(0.16)$ & $5.94(0.16)$ & $2.41(0.12)$ \\
\hline \multirow[t]{2}{*}{ WR } & Pseudotsuga menziesii (psme) & $19.88(0.40)$ & $25.83(0.50)$ & $5.11(0.28)$ & $0.87(0.05)$ \\
\hline & Tsuga heterophylla (tshe) & $20.52(0.53)$ & $25.51(0.17)$ & $4.66(0.37)$ & $0.90(0.02)$ \\
\hline
\end{tabular}

\footnotetext{
${ }^{a}$ The asterisks indicate the significant differences between the two species for the leaf physiological parameters included in the table as assessed through independent sample $t$ test.

${ }^{*} p<0.05$.

${ }^{* *} p<0.01$.

${ }^{* * *} p<0.001$.
}

\section{Discussion}

\subsection{Relationship Between Canopy $\% \mathrm{~N}$ and $\mathrm{ET}$ and $\mathrm{WUE}_{\mathrm{e}}$ : Implications for Vegetation-Climate Interactions}

Our findings provide new insight into the influences of plant $\mathrm{N}$ status on $\mathrm{C}-\mathrm{H}_{2} \mathrm{O}$ fluxes and WUE. We showed that both $\mathrm{C}$ and $\mathrm{H}_{2} \mathrm{O}$ fluxes were significantly correlated with canopy \%N even when other biological and environmental variables were taken into account. Earlier studies, focusing mostly on $\mathrm{C}$ fluxes, showed a positive effect of canopy $\% \mathrm{~N}$ on forest carbon assimilation [e.g., Kergoat et al., 2008; Ollinger et al., 2008] and GPP [e.g., Fernández-Martínez et al., 2014a], explained by the positive link between foliar $\% \mathrm{~N}$ and $A$ [Evans, 1989; Ollinger et al., 2008; Wright et al., 2004]. Moreover, our observations for the first time provided evidence that forests with high canopy $\% \mathrm{~N}$ also have higher ET, which has important implications for hydrologic cycling and climate. The enhancement of ET to support GPP could affect climate in two ways: (1) higher ET increases water vapor in the atmosphere, and water vapor acts as a greenhouse gas and thereby contributes to warming [Bright et al., 2015], or (2) higher ET enhances cloud formation, which in turn could increase planetary albedo, leading to a cooling effect. Furthermore, enhanced cloud formation could lead to an increase in precipitation at regional scale. The relationship that we observed between ET and canopy $\% \mathrm{~N}$ suggests also that factors affecting canopy \% $\mathrm{N}$ (e.g., $\mathrm{N}$ deposition, disturbances, and forest management) have the potential to influence not only $\mathrm{N}$ and $\mathrm{C}$ cycling but also water and energy exchanges with the atmosphere.

$\mathrm{WUE}_{\mathrm{e}}$ is key moderator that could accentuate or offset the vegetation effects on climate, depending in part on the plant $\mathrm{N}$ status. For instance, we can argue that when GPP and ET vary with similar magnitude at xeric $\mathrm{N}$-limited sites (e.g., ACMF and FUF), WUE $\mathrm{e}_{\mathrm{e}}$ will be close to $1 \mathrm{~g} \mathrm{C} / \mathrm{kg} \mathrm{H}_{2} \mathrm{O}$, resulting in a neutral effect on climate. Conversely, on highly productive, N-rich, mesic forest sites (e.g., MM and HF), the positive effect of the high GPP on climate (i.e., by removing $\mathrm{CO}_{2}$ from the atmosphere) could be partially offset by the increase in ET (i.e., cooling effect) to sustain the $\mathrm{C}$ gain. Clearly, only a modeling approach, which includes both $\mathrm{C}$ and $\mathrm{H}_{2} \mathrm{O}$ fluxes and their relationship with canopy $\% \mathrm{~N}$, can help elucidate the applicability of this suggested coupling between the two canopy fluxes and their feedback to climate across a broader range of sites along moisture and nutrient availability gradients. 


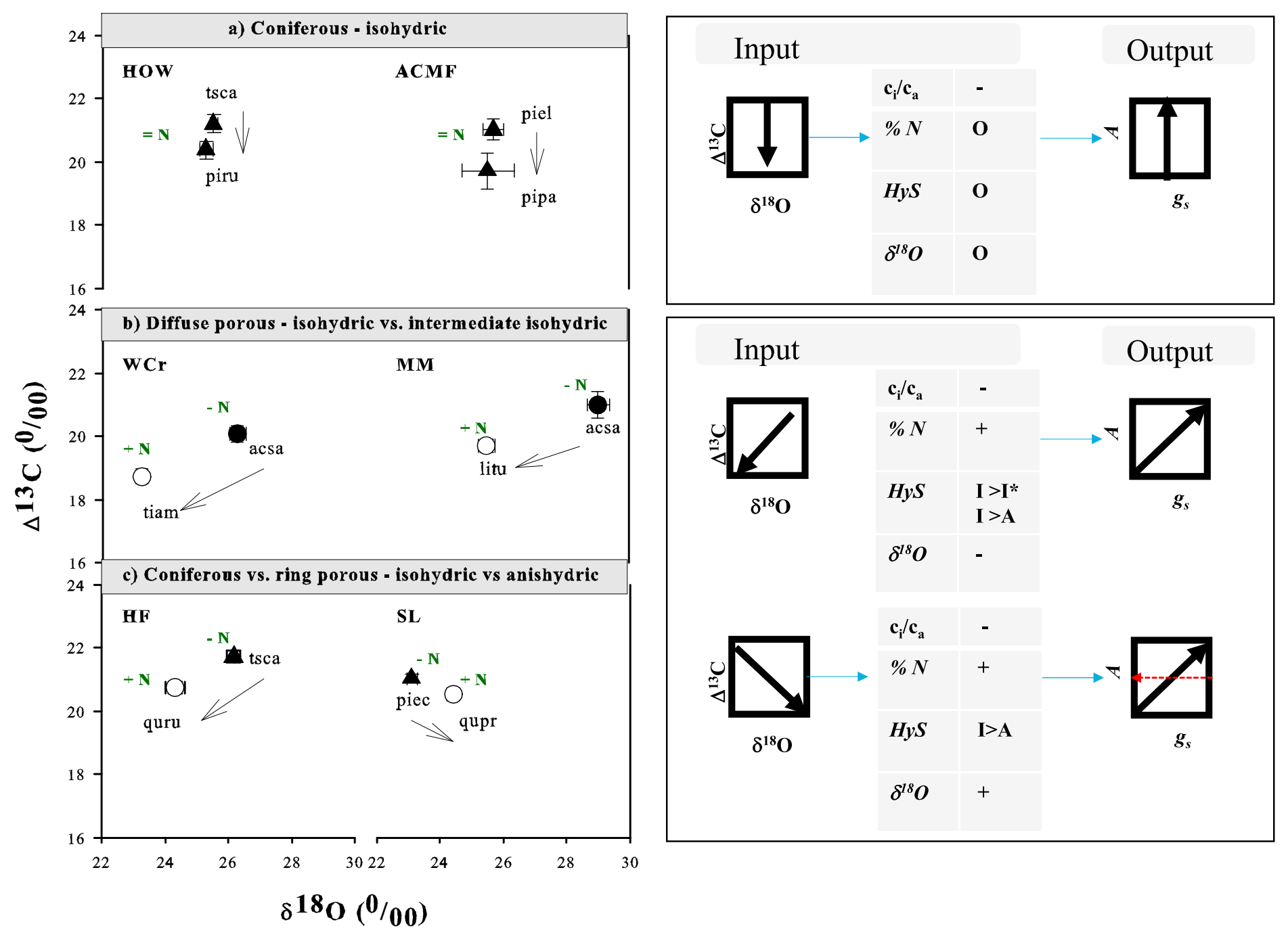

Figure 5. Shifts in foliar $\Delta^{13} \mathrm{C}$ versus $\delta^{18} \mathrm{O}$ for the two dominant species at sites with significant differences between the two species for both isotopes (cf. Table 4). Each value is the mean $( \pm \mathrm{SE}$ ) calculated over 5-10 trees per species. We distinguish three main cases, according to the species' hydraulic strategies (HyS) and wood anatomies (Table S2): (a) coniferous and both isohydric species; (b) diffuse porous species with isohydric and intermediate isohydric strategies; and (c) coniferous versus ring porous species, with isohydric and anisohydric hydraulic strategies, respectively. We also indicated species with higher $(+\mathrm{N})$, lower $(-\mathrm{N})$, and similar $(\mathrm{O})$ foliar $\% \mathrm{~N}$. The directionality in the shifts from species $X$ to species $Y$ goes from high to low $\Delta^{13} \mathrm{C}$ and low to high foliar $\mathrm{N}$. Interpretation of the $\Delta^{13} \mathrm{C}-\delta{ }^{18} \mathrm{O}$ shifts in term of the most likely scenario for changes in $A$ and/or $g_{s}$, based on the Scheidegger et al. [2000] and its modification by Grams et al. [2007], is provided in the plots on the right. As an example, at SL, Quercus prinus (qupr) showed a higher $\delta^{18} \mathrm{O}$ and lower $\Delta^{13} \mathrm{C}$ than the codominant Pinus elliottii (piel). The lower $\Delta^{13} \mathrm{C}$, indicating lower $c_{i} / c_{a}$ ratio, could be related to an increase in $A$ being similar $g_{s}$ or a reduction in $g_{s}$, under similar $A$. Based on the $\delta^{18} \mathrm{O}$ the most likely scenario would be a reduction in $g_{s}$ under similar $A$. However, the higher foliar $\% \mathrm{~N}$ would suggest that divergence between the two species could be also attributed to differences in $A$, with $Q u e r c u s$ likely having higher $A$ than the Pinus species. Moreover, the higher photosynthetic capacity for the Quercus implies greater stomatal opening, facilitated also by its anisohydric strategy, meaning that the species can keep stomata open, even under moderate water stress, in order to maximize $C$ uptake. Thus, the most likely scenarios would be that both $A$ and $g_{s}$ are higher in the Quercus than the Pine species. In this particular case our most likely scenario (i.e., higher $A$ and $g_{s}$ for Quercus compared to Pinus species) does not agree with the one derived from the Scheidegger model, which is indicated with red symbols in the diagram. Anisohydric, isohydric, and intermediate-isohydric species are indicated as $A, l$, and $I^{*}$, respectively.

\subsection{Other Variables Controlling the Spatial Variations in GPP, ET, and WUE}

Latitude, temperature, and species diversity exerted the most control over $\mathrm{C}$ and $\mathrm{H}_{2} \mathrm{O}$ fluxes in our analysis. Forest $\mathrm{C}$ uptake and WUE increased with latitude, while $\mathrm{H}_{2} \mathrm{O}$ lost through ET declined with latitude. Although several previous studies also reported clear latitudinal patterns for $\mathrm{C}$ and $\mathrm{H}_{2} \mathrm{O}$ fluxes and WUE across sites at both regional [Xiao et al., 2013] and global [Luyssaert et al., 2007; Tang et al., 2014; Zhang et al., 2009] scales, other studies did not find clear relationships between GPP and latitude [Law et al., 2002; Magnani et al., 2007; Valentini et al., 2000]. We found that temperature was the main climate factor 
controlling spatial variation in GPP and WUE, but not ET, corroborating findings from previous studies [Chen et al., 2013; Fernández-Martínez et al., 2014b; Law et al., 2002; Luyssaert et al., 2007; Reichstein et al., 2007; Wang and Dickinson, 2012; Xu et al., 2014]. It should be noted that the majority of the above-mentioned studies were based on annual fluxes, while we focused only on May-August months during the growing season. Temperature exerts a strong control on GPP through its influence on leaf photosynthesis [e.g., Berry and Bjorkman, 1980; Sage and Kubien, 2007]. We caution that the relationships between latitude/temperature and fluxes observed in our analysis may also reflect the influence of geographical distributions of forests and intrinsic related features. For instance, the highly productive broadleaf or mixed forests in our analysis (e.g., HF, BEF, and MM) are located at more northern latitudes, as opposed to less productive pine-dominated forests at southern latitudes. Moreover, at a given latitude, there may be different environmental conditions and disturbances (e.g., fires and forest management), which consequently shape the forest-type distributions. As an example, at the same latitude we move from a xeric, low $\mathrm{N}$ availability site dominated by Pinus ponderosa at FUF in the southwestern U.S. to a more mesic forest dominated by broadleaf species-DFHin the southeastern U.S. (Figure 1a). This can partially explain the nonlinear relationship between temperature and fluxes relative to GPP (Figure S4): GPP showed a linear increase up to $25^{\circ} \mathrm{C}$, and thereafter, it declined. However, the lower GPP at $T_{\text {grs }}>25^{\circ} \mathrm{C}$ refers to the pine-dominated forests at ACMF, a xeric site with sandy and low $\mathrm{N}$-available soil [Clark et al., 2004], which is reflected in the low canopy \%N. Lastly, we also acknowledge that the approach of considering GPP during May-August at all sites has the limitation of not taking into account differences across sites in the duration of the growing season. This could lead to an underestimation of fluxes for the sites at southern latitudes, where (i) the duration of growing season can be longer than sites at northern latitudes and (ii) drought conditions during summer can impair $\mathrm{C}$ uptake of forests at xeric versus mesic forests. Despite these shortcomings, we used the fixed time window approach because it allowed us to minimize differences in seasonality between conifer and deciduous species and focus instead on differences in physiological capacity. In addition, our analysis was intended to examine broad-scale patterns of $C$ and $\mathrm{H}_{2} \mathrm{O}$ fluxes in relation to canopy $\% \mathrm{~N}$, rather than to assess specific predictors for GPP, ET, and WUE across the investigated sites.

The significant effect of Shannon's diversity index (SH) on GPP and ET (but not WUE $\mathrm{E}_{\mathrm{e}}$ ) suggests that diversity may have an influence on land-atmosphere exchange that is typically not considered in regional- to globalscale analyses. A number of studies demonstrate a significant and positive effect of biodiversity on forest productivity by using intensive forest inventory data in North America [Liang et al., 2016; Paquette and Messier, 2011; Potter and Woodall, 2014] and China [Liang et al., 2016]. Kunert et al. [2012] reported a linear increase of stand transpiration with tree species richness in an experimental plantation in central Panama, where monocultural and mixed-species plots were established. Baldocchi [2005] reported a significant, but negative, relationship between $\mathrm{ET}$ normalized by the rate of equilibrium evaporation and the number of dominant species, although that analysis was based on data from only six EC broadleaf forests in the U.S. However, because species diversity is known to covary with a number of factors that also affect ecosystem functioning, additional research is needed before a causal relationship can be established.

\subsection{Reconciling Leaf and Ecosystem WUE Estimates}

Leaf and ecosystem WUE showed opposing trends with higher WUE $\mathrm{vpd}_{1}$ and lower $\mathrm{WUE}_{\mathrm{e}}$ at the more xeric (Figure S2 and Table 2) compared to mesic sites, while no significant relationship was found between $W U E_{v p d}$ and $W U E_{e}$. The pattern observed for WUE $E_{v p d 1}$ suggests stomatal closure to prevent $\mathrm{H}_{2} \mathrm{O}$ loss as the main underlying mechanism of changes in leaf WUE under drier conditions [Farquhar and Sharkey, 1982; Niinemets and Keenan, 2014, and reference therein]. At the ecosystem scale, variability in forest structure, LAl, canopy architecture and associated aerodynamic resistance, species composition, and convergence or divergence in the species-specific responses to environmental conditions can all influence canopy ET [Baldocchi, 2005] and consequently WUE. The lower $W_{U E}$ observed at the xeric versus mesic sites may be explained by soil water deficit coupled with high VPD leading to a reduction in $g_{s}$, even though ET did not show a clear pattern across the investigated sites (Table 2). The lower $g_{s}$ would downregulate $A$ more than $E$, resulting in a stronger reduction in the case of GPP compared to ET. Moreover, high temperature and saturated irradiance can affect the Rubisco specificity for $\mathrm{CO}_{2}$ and $\mathrm{O}_{2}$ and favor photorespiration [Farquhar, 1980; Valentini et al., 1995] and mitochondrial respiration [Atkin et al., 2007] over photosynthesis, thus contributing to reducing $C$ uptake and $\mathrm{WUE}_{\mathrm{e}}$. 
The two approaches agreed when we considered the $\Delta{ }^{13} \mathrm{C}$ and hence the $c_{i} / c_{a}$ and GPP. Indeed, we found that the $c_{i} / c_{a}$ was positively correlated with GPP: a lower $c_{i} / c_{a}$ at the lower GPP (and canopy $\% \mathrm{~N}$ ) measured at the xeric sites implies a greater stomatal limitation on $\mathrm{CO}_{2}$ assimilation [Farquhar et al., 1989] and consequently GPP. This suggests that $\Delta^{13} \mathrm{C}$ can be considered among the physiological traits to assess forest productivity [Bonan et al., 2012], as has been observed in a dendro-isotopic study at Harvard forest [Belmecheri et al., 2014].

Differences in the WUE trends observed at the leaf versus ecosystem scales may also, in part, be due to the uncertainties associated with the two approaches. A limitation of the stable isotope approach used in this study is that the effect of mesophyll conductance $\left(g_{m}\right)$ on $\Delta^{13} \mathrm{C}$ was not taken into account, which could be particularly important for trees subjected to drought [Grassi and Magnani, 2005; Warren, 2008]. For instance, not including $g_{m}$ in equation (3) underestimates the $c_{i} / c_{a}$ ratio, which in turn could lead to an overprediction of iWUE [Flanagan and Farquhar, 2014; Seibt et al., 2008]. Moreover, as $g_{m}$ also affects the $\mathrm{CO}_{2}$ concentration in the chloroplast and N use efficiency [Buckley and Warren, 2014], its exclusion could also help explain the lack of a significant relationship between foliar WUE and \%N (Figure 4).

Another limitation in our study was that stable isotopes were measured in bulk foliar tissue, which comprises a combination of different compounds (e.g., protein, lignin, and cellulose), each having a specific isotopic signature reflecting different metabolic pathways and turnover rates [Badeck et al., 2005; Cernusak et al., 2009], thus confounding estimates of $c_{i} / c_{a}$ from $\delta^{13} C$. For instance, Scartazza et al. [2014] found that WUE derived from $\delta^{13} \mathrm{C}$ measured in leaf soluble sugars were more similar to values of $\mathrm{EC}$-derived $\mathrm{WUE}_{\mathrm{e}}$ compared to the estimate from $\delta^{13} \mathrm{C}$ in bulk foliar samples. The authors attributed these results to the different time periods during which distinct $C$ pools were assimilated rather than to inherent differences in the chemical composition, in agreement with results obtained by Brugnoli et al. [1988]. Similarly, Ponton et al. [2006] found good agreement between WUE estimated from EC and ecosystem-respired $\delta^{13} \mathrm{C}$ measurements. Conversely, studies in which leaf WUE was derived from $\delta^{13} C$ in foliar bulk samples [Monson et al., 2010] or leaf gas exchange measurements [Niu et al., 2011] reported difference between leaf and ecosystem WUE estimates. In addition, it should be noted that, for conifer species, we pooled multiple-year needles, which reflect the contribution of different $C$ pools (i.e., newly assimilated carbon in the current year and carbon fixed in the previous years).

The difference between results from leaf and ecosystem scale approaches may also be due in part to differences in the temporal and spatial resolutions of the measurements; EC provides almost instantaneous and continuous measurements during the growing season, while the foliar $\delta^{13} \mathrm{C}$ signal is integrated over the growing season and/or multiple years (e.g., when considering conifers). The $\delta^{13} \mathrm{C}$ in this study reflects the physiological signal as expressed by Sun leaves collected at the top of the canopy, whereas canopy $A$, expressed by GPP, reflects the contribution of both Sun and shade leaves and is affected by canopy structure and associated changes in the leaf properties [Baldocchi et al., 2002].

Lastly, the incongruence between leaf- and canopy-scale WUE estimates may be partly associated with errors and uncertainties in the $\mathrm{C}$ and $\mathrm{H}_{2} \mathrm{O}$ fluxes [Desai et al., 2008; Loescher et al., 2006; Papale et al., 2006; Post et al., 2015] as well as with differences in the ecosystem components contributing to the ET estimates. Uncertainties in EC measurements can result from random errors caused by measurement instruments and footprint heterogeneity [Richardson et al., 2006] and systematic errors caused by suboptimal conditions for micrometeorology or terrain [Baldocchi, 2003]. The EC technique relies on specific biophysical conditions (e.g., turbulence in the boundary layer and steady state conditions of the meteorological variables) to derive $C$ and energy fluxes. Error and uncertainty are introduced when these conditions are not met; in particular, measurement of nighttime NEE fluxes-which are used to derive both RE and GPP_can be challenging due to low nighttime turbulence [Reichstein et al., 2005]. EC estimates can also be affected by variability in the flux tower measurement footprint due to the patchiness of the forest structure, canopy roughness, complex terrain, and the temporal variability of wind direction. Moreover, for forests at northern latitudes (e.g., HOW) and high elevation (e.g., NR), the duration of snow cover or timing and variability of snowmelt could affect both soil water and energy balance [Monson et al., 2010], thus affecting ET estimates. Additional error that can include both random and systematic components can be introduced by filling data gaps and partitioning of NEE into GPP and RE [Wehr et al., 2016]. Finally, cross-site synthesis studies such as the one presented here can also include error associated with differences in data processing among sites. Although many of these errors cannot be 
eliminated, we minimized their influence by using the same quality-type data (level 4), based on the same procedures for both gap filling and partitioning of $C$ fluxes at all sites.

In addition to error associated with individual measurements, differences between leaf- and ecosystem-scale estimates could also be due to differences in the ecosystem components represented. Whereas leaf-level stable isotope measurements can only capture patterns of individual leaves, EC-derived ET and GPP data include both canopy and understory fluxes and in the case of ET, evaporation from soils. The contribution of the understory to ecosystem ET becomes progressively more important in low LAI ecosystems, particularly the southern conifer forests. For example, ACMF is characterized by a dense understory dominated by saw palmetto, which was shown to contribute to $C$ fluxes [Powell et al., 2008] and likely also to ET. At FUF, the understory vegetation is sparse ( $\mathrm{LAI}=0.06$ [Dore et al., 2008]) and is mostly characterized by herbaceous species, suggesting that soil evaporation contributed to the ET. Moreover, seasonal changes in LAl, especially in mixed forests, could lead to variations in canopy roughness and aerodynamic resistance, which affect the turbulence in the boundary layer and, consequently, the exchange of carbon, energy, and water between canopies and the atmosphere [Davin and de Noblet-Ducoudré, 2010].

\subsection{Incorporating Species' Functional Traits in a Conceptual Model to Interpret Foliar $\Delta^{13} \mathrm{C}$ and $\delta^{18} \mathrm{O}$}

Species functional traits can directly affect the response of plant $\mathrm{C}$ and $\mathrm{H}_{2} \mathrm{O}$ fluxes to climate change at the regional and/or global scale but are seldom included in model parameterization or cross-site comparisons of canopy fluxes. For instance, foliar \% $\mathrm{N}$ is an important determinant of $A$ [Wright et al., 2004], which in turn affects the $c_{i} / c_{a}$ ratio and hence the $\Delta^{13} \mathrm{C}$. On the other hand, wood anatomy and hydraulic strategies play a significant role in regulating the tree water transport and stomatal regulation, which affects the oxygen isotopic signature in leaf water and the organic matter formed in it.

In this study we modified the original dual-isotope conceptual model proposed by Scheidegger et al. [2000] and further developed by Grams et al. [2007] by incorporated species' physiological traits related to wood anatomical features, hydraulic strategies, and foliar $\% \mathrm{~N}$ to improve model representation of $A$ and $g_{s}$, as derived from $\Delta^{13} \mathrm{C}$ and $\delta^{18} \mathrm{O}$, respectively. As we expected, within two coniferous forests where the two dominant species can both be classified as isohydric, HOW in the Northeast and ACMF in the Southeast, we found differences between codominant species in $\Delta^{13} \mathrm{C}$ but not $\delta^{18} \mathrm{O}$. This suggests that differences in the $c_{i} / c_{a}$ could likely be attributed to differences in $A$ (Figure $5 a$ ), which, however, lead to a difference in the WUE $_{\mathrm{vpd} 1}$ between the two species only in the case of ACMF. Given that foliar $\% \mathrm{~N}$ was similar between the two conifer species, we can also infer that differences in $A$ could be related to differences in mesophyll conductance and/or nonstomatal limitations, i.e., those related to the light use efficiency (electron transport), or Rubisco activity [Grassi and Magnani, 2005; Flexas et al., 2014], particularly at the more xeric site in Florida (ACMF).

In forests characterized by the codominance of tree species with contrasting hydraulic strategies (foliar \% $\mathrm{N}$ isohydric versus anisohydric, or isohydric versus intermediate isohydric) we observed differences in both $\Delta^{13} \mathrm{C}$ and $\delta^{18} \mathrm{O}$ between the two species, which indicate differences in both $A$ and $g_{s}$ (Figures $5 \mathrm{~b}$ and $5 \mathrm{c}$ ). The lower $c_{i} / c_{a}$ for $L$. tulipifera at WCr and MM and Q. rubra at HF could be related either to higher $A$ at similar $g_{s}$ or lower $g_{s}$ at similar $A$ compared to the codominant species. However, according to the dual-isotope model, the direction of change in $\delta^{18} \mathrm{O}$ (Figure $5 \mathrm{~b}$ ) suggests both a higher $A$ and a higher $g_{s}$ as the most likely scenario explaining the differences between the two species in $\mathrm{WUE}_{\mathrm{vpd} 1}$. This interpretation is further supported by the higher foliar $\% \mathrm{~N}$ and the anisohydric strategy of $Q$. rubra and intermediate isohydric $L$. tulipifera compared to the corresponding codominant species for each site (HF: T. canadensis and MM: A. saccharum, respectively). This is also consistent with the results from gas exchange data reported in previous studies. Indeed, Roman et al. [2015] reported a lower $A$ and $g_{s}$ for $A$. saccharum versus $L$. tulipifera at MM. Leaf gas exchange measurements at HF confirmed that $T$. canadensis had lower $g_{s}$ and also lower photosynthetic rate compared to the Q. rubra [Catovsky and Bazzaz, 2002]. Moreover, direct measurements of sap flux on A. saccharum and $T$. americana showed that the latter maintained higher transpiration rates than the former in a northern Wisconsin forest [Ewers et al., 2007] near the WCr site, suggesting a higher $g_{s}$ and likely $A$.

In contrast to these cases where our modified conceptual model provided additional supporting evidence for the interpretations obtained using the original Scheidegger model and its further development by Grams et al. [2007], our results diverged for the SL site. The mixed forest at SL grows on a deep, sandy soil with 
limited water and nutrient-holding capacity [Renninger et al., 2014]. At this site, Q. prinus (anisohydric) exhibited a lower $\Delta^{13} \mathrm{C}, \delta^{18} \mathrm{O}$, and $c_{i} / c_{a}$ compared to the codominant $P$. echinata (isohydric). The lower $c_{i} / c_{a}$ together with the higher foliar $\% \mathrm{~N}$ would suggest that divergence between the two species are attributed to differences in $A$, with oak likely having higher $A$ than the pine. However, the higher photosynthesis for the Quercus species implies greater $g_{s}$ than the codominant isohydric Pinus species, likely facilitated by its hydraulic strategy: anihysodric species with ring porous xylem vessels, which can more rapidly transport water and supply it to the canopy to sustain photosynthesis. In this case, the Scheidegger model would predict a reduction in $g_{s}$ with no change in $A$ (Figure 5), which we excluded as the most likely scenario given the differences between the two species in their hydraulic strategies and foliar \%N.

We acknowledge that this conceptual model should be used with cautions [Roden and Farquhar, 2012; Roden and Siegwolf, 2012], especially when interpreting qualitative changes in the integrated $g_{s}$ from $\delta^{18} \mathrm{O}$. Furthermore, tree species can show a hydraulic strategy, which can be intermediate along isohydric and anisohydric gradients [Martínez-Vilalta et al., 2014]. However, our observations suggest that a more robust and physiologically based prediction of $A$ and $g_{s}$ could be gleaned from the conceptual model by taking additional functional traits into account, particularly foliar \%N.

\section{Conclusion}

Several conclusions can be drawn from our results. First, we demonstrated that, in addition to GPP, ET and WUE were significantly and positively correlated with canopy $\% \mathrm{~N}$, even when environmental variables were taken into account. Whereas feedback of $\mathrm{C}, \mathrm{N}$, and $\mathrm{H}_{2} \mathrm{O}$ fluxes to climate tend to be assessed separately, these findings suggest that understanding the role of forests in mitigating climate change requires a more holistic approach [Betts, 2007]. Second, leaf and ecosystem WUE showed opposing trends, with higher WUE $\mathrm{vpd}_{1}$ at the more xeric compared to mesic sites suggesting stomatal closure to prevent $\mathrm{H}_{2} \mathrm{O}$ loss as the main underlying mechanism of changes in leaf WUE. Nevertheless, the significant positive relationship we observed between GPP and the foliar $c_{i} / c_{a}$ is a promising result that helps reconcile the two scales and approaches. This suggests that $\Delta^{13} \mathrm{C}$ (and the derived $c_{i} / c_{a}$ ) could be useful as predictors of GPP, especially when species-specific contributions are of interest. Third, the dual-isotope approach revealed that highly productive forests were characterized by the presence of dominant species that diverged in their physiological traits, regardless of plant functional type. Indeed, species having anisohydric (HF and SL) or intermediate isohydric (MM and WCr) strategies may play a key role in ecosystem functioning, i.e., by allowing loss of water in order to maximize $\mathrm{C}$ gain. We showed that the dual-isotope approach can be improved by integrating foliar $\% \mathrm{~N}$, wood anatomical, and hydraulic strategies as input, in order to gain a more robust interpretation of $\Delta^{13} \mathrm{C}$ and $\delta^{18} \mathrm{O}$ in terms of $A$ and $g_{s}$ so to link leaf and ecosystem $\mathrm{C}$ and $\mathrm{H}_{2} \mathrm{O}$ fluxes.

\section{References}

Anav, A., et al. (2015), Spatiotemporal patterns of terrestrial gross primary production: A review, Rev. Geophys, 53, 785-818, doi:10.1002/ 2015 RG000483.

Atkin, O. K., I. Scheurwater, and T. L. Pons (2007), Respiration as a percentage of daily photosynthesis in whole plants is homeostatic at moderate, but not high, growth temperatures, New Phytol., 174, 367-380, doi:10.1111/j.1469-8137.2007.02011.x.

Badeck, F. W., G. Tcherkez, S. Nogues, C. Piel, and J. Ghashghaie (2005), Post-photo synthetic fractionation of stable carbon isotopes between plant organs-A widespread phenomenon, Rapid Commun. Mass Spectrom., 19, 1381-1391.

Baldocchi, D. D. (2003), Assessing the eddy covariance technique for evaluating carbon dioxide exchange rates of ecosystems: Past, present and future, Global Change Biol., 9, 479-492.

Baldocchi, D. D. (2005), The role of biodiversity on the evaporation of forests, in Forest Diversity and Function: Temperate and Boreal Systems, edited by M. Scherer-Lorenzen, C. H. Körner, and E. D. Schulze, Springer, Berlin.

Baldocchi, D. D. (2008), Breathing of the terrestrial biosphere: Lessons learned from a global network of carbon dioxide flux measurement systems, Aust. J. Bot., 56, 1-26.

Baldocchi, D. D., et al. (2001), FLUXNET: A new tool to study the temporal and spatial variability of ecosystem-scale carbon dioxide, water vapor, and energy flux densities, Bull. Am. Meteorol. Soc., 82, 2415-2434.

Baldocchi, D. D., K. B. Wilson, and L. Gu (2002), How the environment, canopy structure and canopy physiological functioning influence carbon, water and energy fluxes of a temperate broad-leaved deciduous forest-an assessment with the biophysical model CANOAK, Tree Physiol., 22(15-16), 1065-1077.

Barbour, M. M. (2007), Stable oxygen isotope composition of plant tissue: A review, Funct. Plant Biol., 34, 83-94.

Barbour, M. M., R. A. Fischer, K. D. Sayre, and G. D. Farquhar (2000), Oxygen isotope ratio of leaf and grain material correlates with stomatal conductance and yield in irrigated, field-grown wheat, Aust. J. Plant Physiol., 27, 625-637.

Barbour, M. M., J. S. Roden, G. D. Farquhar, and J. R. Ehleringer (2004), Expressing leaf water and cellulose oxygen isotope ratios as enrichment above source water reveals evidence of a Péclet effect, Oecologia, 138, 426-435, doi:10.1007/s00442-003-1449-3.

$\% \mathrm{~N}$ and isotope data for individual trees at each site can be requested to the corresponding author. 
Barnard, H. R., J. R. Brooks, and B. J. Bond (2012), Applying the dual-isotope conceptual model to interpret physiological trends under uncontrolled conditions, Tree Physiol., 32(10), 1183-1198.

Beer, C., et al. (2009), Temporal and among-site variability of inherent water use efficiency at the ecosystem level, Global Biogeochem. Cycles, 23, GB2018, doi:10.1029/2008GB003233.

Belmecheri, S., R. S. Maxwell, A. H. Taylor, K. J. Davis, K. H. Freeman, and W. J. Munger (2014), Tree-ring $\delta^{13} \mathrm{C}$ tracks flux tower ecosystem productivity estimates in a NE temperate forest, Environ. Res. Lett., 9, 074011, doi:10.1088/1748-9326/9/7/074011.

Berry, J., and O. Bjorkman (1980), Photosynthetic response and adaptation to temperature in higher plants, Ann. Rev. Plant Physiol, 31, 491-543.

Betts, R. (2007), Implications of land ecosystem-atmosphere interactions for strategies for climate change adaptation and mitigation, Tellus $B$ 59, 602-615, doi:10.1111/j.1600-0889.2007.00284.x.

Bolster, K. L., M. E. Martin, and J. D. Aber (1996), Determination of carbon fraction and nitrogen concentration in tree foliage by near infrared reflectances: A comparison of statistical methods, Can. J. For. Res., 26, 590-600.

Bonan, G. B. (2008), Forests and climate change: Forcings, feedbacks, and the climate benefits of forests, Science, 320(5882), $1444-1449$.

Bonan, G. B., K. W. Oleson, R. A. Fisher, G. Lasslop, and M. Reichstein (2012), Reconciling leaf physiological traits and canopy flux data: Use of the TRY and FLUXNET databases in the Community Land Model version 4, J. Geophys. Res., 117, G02026, doi:10.1029/2011JG001913.

Bright, R. M., K. Zhao, R. B. Jackson, and F. Cherubini (2015), Quantifying surface albedo and other direct biogeophysical climate forcings of forestry activities, Global Change Biol., 21, 3246-3266.

Brugnoli, E., K. T. Hubick, S. von Caemmerer, S. C. Wong, and G. D. Farquhar (1988), Correlation between carbon isotope discrimination in leaf starch and sugars of $C_{3}$ plants and the ratio of intercellular and atmospheric partial pressures of carbon dioxide, Plant Physiol., 88, 1418-1424.

Buckley, T. N., and C. R. Warren (2014), The role of mesophyll conductance in the economics of nitrogen and water use in photosynthesis, Photosynth. Res., 119(1), 77-88.

Canadell, J. G., C. Le Quéré, M. R. Raupach, C. B. Field, E. T. Buitenhuis, P. Ciais, T. J. Conway, N. P. Gillett, R. A. Houghton, and G. Marland (2007), Contributions to accelerating atmospheric $\mathrm{CO}_{2}$ growth from economic activity, carbon intensity, and efficiency of natural sinks, Proc. Natl. Acad. Sci. U. S. A., 104(47), 18,866-18,870.

Carnicer, J., A. Barbeta, D. Sperlich, M. Coll, and J. Penñuelas (2013), Contrasting trait syndromes in angiosperms and conifers are associated with different responses of tree growth to temperature on a large scale, Front. Plant Sci., 4, 409, doi:10.3389/fpls.2013.00409.

Catovsky, S., and F. A. Bazzaz (2002), Contributions of coniferous and broad-leaved species to temperate forest carbon uptake: A bottom-up approach, Can. J. For. Res., 30, 100-111.

Cernusak, L. A., et al. (2009), Why are non-photosynthetic tissues generally ${ }^{13} \mathrm{C}$ enriched compared to leaves in C3 plants? Review and synthesis of current hypotheses, Funct. Plant Biol., 36, 199-213.

Chen, Z., et al. (2013), Temperature and precipitation control of the spatial variation of terrestrial ecosystem carbon exchange in the Asian region, Agric. For. Meteorol., 182-183, 266-276.

Clark, K. L., H. L. Gholz, and M. S. Castro (2004), Carbon dynamics along a chronosequence of slash pine plantations in north Florida, Ecol. Appl., 14, 1154-1171.

Craig, H., and L. I. Gordon (1965), Deuterium and oxygen-18 variations in the ocean and the marine atmosphere, in Proceedings of Conference on Stable Isotopes on Oceanographic Studies and Paleotemperatures, edited by T. Tongiorgi, pp. 9-130, Lischi and Figli, Pisa, Italy.

Davin, E. L., and N. de Noblet-Ducoudré (2010), Climatic impact of global-scale deforestation: Radiative versus nonradiative processes, J. Clim., 23, 97-112.

Desai, A. R., et al. (2008), Cross-site evaluation of eddy covariance GPP and RE decomposition techniques, Agric. For. Meteorol., 148(6-7), 821-838.

Dickinson, R. E., et al. (2002), Nitrogen controls on climate model evapotranspiration, J. Clim., 15, 278-295.

Dongmann, G., H. E. Nurnberg, H. Forstel, and K. Wagener (1974), On the enrichment of $\mathrm{H}_{2}{ }^{18} \mathrm{O}$ in the leaves of transpiring plants, Radiat. Environ. Biophys., 11, 41-52, doi:10.1007/BF01323099.

Donovan, L. A., and J. R. Ehleringer (1994), Carbon isotope discrimination, water-use efficiency, growth and mortality in a natural shrub population, Oecologia, 100, 347-354.

Dore, S., T. E. Kolb, M. Montes-Helu, B. W. Sulivan, W. D. Winslow, S. C. Hart, J. P. Kaye, G. W. Koch, and B. A. Hungate (2008), Long-term impact of a stand-replacing fire on ecosystem CO2 exchange of a ponderosa pine forest, Global Change Biol., 14, 1801-1820, doi:10.1111/j.13652486.2008.01613.x.

Evans, J. R. (1989), Photosynthesis and nitrogen relationships in leaves of $C_{3}$ plants, Oecologia, 78, 9-19.

Ewers, B. E., D. S. Mackay, and S. Samanta (2007), Interannual consistency in canopy stomatal conductance control of leaf water potential across seven tree species, Tree Physiol., 27(1), 11-24.

Farquhar, G. D. (1980), Carbon isotope discrimination by plants: Effects of carbon dioxide concentrations and temperature via the ratio of intercellular and atmospheric $\mathrm{CO}_{2}$ concentration, in Carbon Dioxide and Climate: Australian Research, edited by G. I. Pearman, pp. 105-110, Aust. Acad. of Sci., Canberra.

Farquhar, G. D., and J. Lloyd (1993), Carbon and oxygen isotope effects in the exchange of carbon dioxide between plants and the atmosphere, in Stable Isotope and Plant Carbon-Water Relations, edited by J. R. Ehleringer, A. E. Hall, and G. D. Farquhar, pp. 47-70 , Academic Press, New York.

Farquhar, G. D., and T. D. Sharkey (1982), Stomatal conductance and photosynthesis, Annu. Rev. Plant Physiol., 33, $317-345$.

Farquhar, G. D., M. H. O'Leary, and J. A. Berry (1982), On the relationship between carbon isotope discrimination and intercellular carbon dioxide concentration in leaves, Aust. J. Plant Physiol., 9, 121-137.

Farquhar, G. D., J. R. Ehleringer, and K. T. Hubick (1989), Carbon isotope discrimination and photosynthesis, Annu. Rev. Plant Physiol. Plant Mol. Biol, 40, 503-537.

Federer, C. A., C. J. Vörösmarty, and B. Fekete (1996), Intercomparison of methods for potential evapotranspiration in regional or global water balance models, Water Resour. Res., 32, 2315-2321, doi:10.1029/96WR00801.

Fernández-Martínez, M., et al. (2014a), Nutrient availability as the key regulator of global forest carbon balance, Nature, 4, 471-476.

Fernández-Martínez, M., S. Vicca, I. A. Janssens, S. Luyssaert, M. Campioli, J. Sardans, M. Estiarte, and J. Peñuelas (2014b), Spatial variability and controls over biomass stocks, carbon fluxes, and resource-use efficiencies across forest ecosystems, Trees, 28(2), $597-611$.

Flanagan, L. B., and G. D. Farquhar (2014), Variation in the carbon and oxygen isotope composition of plant biomass and its relationship to water-use efficiency at the leaf- and ecosystem-scales in a northern Great Plains grassland, Plant Cell Environ., 37(2), 425-438.

Flexas, J., A. Diaz-Espejo, J. Gago, A. Gallé, J. Galmés, J. Gulías, and H. Medrano (2014), Photosynthetic limitations in Mediterranean plants: A review, Environ. Exp. Bot., 103, 12-23.

Gessler, A., E. Brandes, C. Keitel, S. Boda, Z. E. Kayler, A. Granier, M. Barbour, G. D. Farquhar, and K. Treydte (2013), The oxygen isotope enrichment of leaf-exported assimilates_Does it always reflect lamina leaf water enrichment?, New Phytol., 200, $144-157$. 
Gessler, A., J. P. Ferrio, R. Hommel, K. Treydte, R. A. Werner, and R. K. Monson (2014), Stable isotopes in tree rings: Towards a mechanistic understanding of isotope fractionation and mixing processes from the leaves to the wood, Tree Physiol., 34, 796-818.

Grams, T. E. E., A. R. Kozovits, K. H. Haberle, R. Matyssek, and T. E. Dawson (2007), Combining $\delta^{13} \mathrm{C}$ and $\delta^{18} \mathrm{O}$ analyses to unravel competition $\mathrm{CO}_{2}$ and $\mathrm{O}_{3}$ effects on the physiological performance of different-aged trees, Plant, Cell Environ., 30, 1023-1034.

Grassi, G., and F. Magnani (2005), Stomatal, mesophyll conductance and biochemical limitations to photosynthesis as affected by drought and leaf ontogeny in ash and oak trees, Plant Cell Environ., 28, 834-849.

Guerrieri, R., M. Mencuccini, L. J. Sheppard, M. Saurer, M. P. Perks, P. Levy, M. A. Sutton, M. Borghetti, and J. Grace (2011), The legacy of enhanced $\mathrm{N}$ and $\mathrm{S}$ deposition as revealed by the combined analysis of $\delta^{13} \mathrm{C}, \delta^{18} \mathrm{O}$ and $\delta^{15} \mathrm{~N}$ in tree rings, Global Change Biol., 17 , $1946-1962$.

Heimann, M.,and M. Reichstein (2008), Terrestrial ecosystem carbon dynamics and climate feedbacks, Nature, 451, 289-292.

Jennings, K. A., R. Guerrieri, M. A. Vadeboncoeur, and H. Asbjorsen (2016), Response of Quercus velutina growth and water use efficiency to climate variability and nitrogen fertilization in a temperate deciduous forest in the northeastern USA, Tree Physiol., 36, 428-443, doi:10.1093/treephys/tpw003.

Keenan, T. F., D. Y. Hollinger, G. Bohrer, D. Dragoni, J. W. Munger, H. P. Schmid, and A. D. Richardson (2013), Increase in forest water-use efficiency as atmospheric carbon dioxide concentrations rise, Nature, 499, 324-327.

Keitel, C., M. A. Adams, T. Holst, A. Matzarakis, H. Mayer, H. Rennenberg, and A. Gessler (2003), Carbon and oxygen isotope composition of organic compounds in the phloem sap provides a short term measure for stomatal conductance of European beech (Fagus sylvatica L.), Plant Cell Environ., 26, 1157-1168.

Kergoat, L., S. Lafont, A. Arneth, V. Le Dantec, and B. Saugier (2008), Nitrogen controls plant canopy light-use efficiency in temperate and boreal ecosystems, J. Geophys. Res., 113, G04017, doi:10.1029/2007JG000676.

Kunert, N., L. Schwendenmann, C. Potvin, and D. Hölscher (2012), Tree diversity enhances tree transpiration in a Panamanian forest plantation, J. Appl. Ecol., 49, 135-144.

Law, B. E., et al. (2002), Environmental controls over carbon dioxide and water vapor exchange of terrestrial vegetation, Agric. For. Meteorol., $113,97-120$.

Lee, E., B. S. Felzer, and Z. Kothavala (2013), Effects of nitrogen limitation on hydrological processes in CLM4-CN, J. Adv. Model. Earth Syst., 5, 741-754, doi:10.1002/jame.20046.

Leonelli, G., G. Battipaglia, R. T. W. Siegwolf, M. Saurer, U. M. di Cella, P. Cherubini, and M. Pelfini (2012), Climatic isotope signals in tree rings masked by air pollution: A case study conducted along the Mont Blanc Tunnel access road (Western Alps, Italy), Atmos. Environ., 61, 169-179.

Lepine, L., C. S. V. Ollinger, A. P. Ouimette, and M. Martin (2016), Examining spectral reflectance features related to foliar nitrogen in forests: Implications for broad-scale nitrogen mapping, Remote Sens. Environ., 173, 174-186.

Lévesque, M., R. Siegwolf, M. Saurer, B. Eilmann, and A. Rigling (2014), Increased water-use efficiency does not lead to enhanced tree growth under xeric and mesic conditions, New Phytol., 203, 94-109, doi:10.1111/nph.12772.

Liang, J., J. V. Watson, M. Zhou, and X. Lei (2016), Effects of productivity on biodiversity in forest ecosystems across the United States and China, Conserv. Biol., doi:10.1111/cobi.12636.

Loescher, H., W. B. E. Law, L. Mahrt, D. Y. Hollinger, J. Campbell, and S.,. C. Wofsy (2006), Uncertainties in, and interpretation of, carbon flux estimates using the eddy covariance technique, J. Geophys. Res., 111, D21S90, doi:10.1029/2005JD006932.

Luyssaert, S., et al. (2007), $\mathrm{CO}_{2}$ balance of boreal, temperate, and tropical forests derived from a global database, Global Change Biol., 13, 2509-2537, doi:10.1111/j.1365-2486.2007.01439.x.

Magnani, F., et al. (2007), The human footprint in the carbon cycle of temperate and boreal forests, Nature, 447, 848-850.

Martin, M. E., L. C. Plourde, S. V. Ollinger, M.-L. Smith, and B. E. McNeil (2008), A generalizable method for remote sensing of canopy nitrogen across a wide range of forest ecosystems, Remote Sens. Environ., 112, 3511-3519.

Martínez-Vilalta, J., R. Poyatos, D. Aguadé, J. Retana, and M. Mencuccini (2014), A new look at water transport regulation in plants, New Phytol., 204, 105-115, doi:10.1111/nph.12912.

Meinzer, F. C., D. R. Woodruff, D. M. Eissenstat, H. S. Lin, T. S. Adams, and K. A. McCulloh (2013), Above- and belowground controls on water use by trees of different wood types in an eastern US deciduous forest, Tree Physiol., 33, 345-356, doi:10.1093/treephys/tpt012.

Meir, P., P. Cox, and J. Grace (2006), The influence of terrestrial ecosystems on climate, Trend Ecol. Evolution, 21(5), $254-260$.

Michelot, A., T. Eglin, E. Dufrêne, C. Lelarge-Trouverie, and C. Damesin (2011), Comparison of seasonal variations in water-use efficiency calculated from the carbon isotope composition of tree rings and flux data in a temperate forest, Plant cell Environ., 34, $230-244$.

Moffat, A. M., et al. (2007), Comprehensive comparison of gap-filling techniques for eddy covariance net carbon fluxes, Agric. For. Meteorol., 147, 209-232.

Monson, R. K., M. R. Prater, J. Hu, S. P. Burns, J. P. Sparks, K. L. Sparks, and L. E. Scott-Denton (2010), Tree species effects on ecosystem wateruse efficiency in a high-elevation, subalpine forest, Oecologia, 162(2), 491-504.

Moreno-Gutiérrez, C., T. E. Dawson, E. Nicolás, and J. I. Querejete (2012), Isotopes reveal contrasting water use strategies among coexisting plant species in a Mediterranean ecosystem, New Phytol., 196, 489-496.

Niinemets, Ü., and T. Keenan (2014), Photosynthetic responses to stress in Mediterranean evergreens: Mechanisms and models, Environ. Exp. Bot., 103, 24-41.

Niu, S., X. R. Xing, Z. Zhang, J. Y. Xia, X. H. Zhou, B. Song, L. H. Li, and S. Q. Wan (2011), Water-use efficiency in response to climate change: From leaf to ecosystem in a temperate steppe, Global Change Biol., 17(2), 1073-1082.

Ollinger, S. V., and M.-L. Smith (2005), Net primary production and canopy nitrogen in a temperate forest landscape: An analysis using imaging spectroscopy, modeling and field data, Ecosystems, 8, 760-778.

Ollinger, S. V., et al. (2008), Canopy nitrogen, carbon assimilation, and albedo in temperate and boreal forests: Functional relations and potential climate feedbacks, Proc. Natl. Acad. Sci. U.S.A., 105(49), 19,336-19,341.

Pan, Y., et al. (2011), A large and persistent carbon sink in the world's forests, Science, 333, 988-993.

Pan, Y., S. H. Tian, S. R. S. Dangal, Q. Yang, J. Yang, C. Lu, B. Tao, W. Ren, and Z. Ouyang (2015), Responses of global terrestrial evapotranspiration to climate change and increasing atmospheric $\mathrm{CO}_{2}$ in the 21st century, Earth's Future, 3, 15-35, doi:10.1002/2014EF000263.

Papale, D., et al. (2006), Towards a standardized processing of net ecosystem exchange measured with eddy covariance technique: Algorithms and uncertainty estimation, Biogeosciences, 3, 571-583.

Paquette, A., and C. Messier (2011), The effect of biodiversity on tree productivity: From temperate to boreal forests, Global Ecol. Biogeogr., 20, $170-180$.

Ponton, S., L. B. Flanagan, K. P. Alstad, B. G. Johnson, K. Morgestern, N. Kljun, T. A. Black, and A. G. Barr (2006), Comparison of ecosystem wateruse efficiency among Douglas-fir forest, aspen forest and grassland using eddy covariance and carbon isotope techniques, Global Change Biol., 12, 294-310, doi:10.1111/j.1365-2486.2005.01103.x. 
Post, H., H. J. Hendricks Franssen, A. Graf, M. Schmidt, and H. Vereecken (2015), Uncertainty analysis of eddy covariance $\mathrm{CO}_{2}$ flux measurements for different EC tower distances using an extended two-tower approach, Biogeosciences, 12, 1205-1221.

Potter, K. M., and C. W. Woodall (2014), Does biodiversity make a difference? Relationships between species richness, evolutionary diversity, and aboveground live tree biomass across U.S. forests, For. Ecol. Manage., 321, 117-129.

Powell, T. L., H. L. Gholz, K. L. Clark, G. Starr, W. P. Cropper, and T. A. Martin (2008), Carbon exchange of a mature, naturally regenerated pine forest in north Florida, Global Change Biol., 14, 2523-2538, doi:10.1111/j.1365-2486.2008.01675.x.

R Core Team (2014), R: A language and environment for statistical computing, R Foundation for Statistical Computing Vienna, Austria. [Available at http://www.R-project.org.]

Reichstein, M., et al. (2005), On the separation of net ecosystem exchange into assimilation and ecosystem respiration: Review and improved algorithm, Global Change Biol., 11(9), 1424-1439.

Reichstein, M., et al. (2007), Determinants of terrestrial ecosystem carbon balance inferred from European eddy covariance flux sites, Geophys. Res. Lett., 34, L01402, doi:10.1029/2006GL027880.

Renninger, H. J., N. Carlo, K. L. Clark, and K. V. R. Schäfer (2014), Physiological strategies of co-occurring oaks in a water- and nutrient-limited ecosystem, Tree Physiol., 34(2), 159-173.

Richardson, A. D., et al. (2006), A multi-site analysis of random error in tower-based measurements of carbon and energy fluxes, Agric. For. Meteorol., 136, 1-18.

Ripullone, F., M. R. Guerrieri, M. Saurer, R. Siegwolf, M. Jäggi, R. Guarini, and F. Magnani (2009), Testing a dual isotope model to track carbon and water gas exchanges in a Mediterranean forest, iForest Biogeosci. For., 2, 59-66.

Roden, J., and G. Farquhar (2012), A controlled test of the dual-isotope approach for the interpretation of stable carbon and oxygen isotope ratio variation in tree rings, Tree Physiol., 32(4), 490-503.

Roden, J., and R. Siegwolf (2012), Is the dual-isotope conceptual model fully operational?, Tree Physiol., 32(10), $1179-1182$.

Roden, J., A. Kahmen, N. Buchmann, and R. Siegwolf (2015), The enigma of effective path length for ${ }^{18} \mathrm{O}$ enrichment in leaf water of conifers, Plant Cell Environ., 38(12), 2551-2565.

Roman, D. T., K. A. Novick, E. R. Brzostek, D. Dragoni, F. Rahman, and R. P. Phillips (2015), The role of isohydric and anisohydric species in determining ecosystem-scale response to severe drought, Oecologia, 179(3), 641-654.

Sage, R. F., and D. S. Kubien (2007), The temperature response of C3 and C4 photosynthesis, Plant Cell Environ., 30, $1086-1106$.

Scartazza, A., F. P. Vaccari, T. Bertolini, P. Di Tommasi, M. Lauteri, F. Miglietta, and E. Brugnoli (2014), Comparing integrated stable isotope and eddy covariance estimates of water-use efficiency on a Mediterranean successional sequence, Oecologia, 176, 581-594.

Scheidegger, Y., M. Saurer, M. Bahn, and R. T. W. Siegwolf (2000), Linking stable oxygen and carbon isotopes with stomatal conductance and photosynthetic capacity: A conceptual model, Oecologia, 125, 350-357.

Schulze, E.-D. (2006), Biological control of the terrestrial carbon sink, Biogeosciences, 3(2), 147-166.

Seibt, U., A. Rajabi, H. Griffiths, and J. A. Berry (2008), Carbon isotopes and water use efficiency: Sense and sensitivity, Oecologia, 155, 441-454, doi:10.1007/s00442-007-0932-7.

Siegwolf, R. T. W., R. Matyssek, M. Saurer, S. Maurer, M. S. Günthardt-Georg, P. Schmutz, and B. J. Burcher (2001), Stable isotope analysis reveals differential effects of soil nitrogen and nitrogen dioxide on the water use efficiency in hybrid poplar leaves, New Phytol., 149, 233-246.

Smith, M. L., S. V. Ollinger, M. E. Martin, J. D. Aber, R. A. Hallett, and C. L. Goodale (2002), Direct estimation of aboveground forest productivity through hyperspectral remote sensing of canopy nitrogen, Ecol. Appl., 12, 1286-1302.

Smith, M. L., and M. E. Martin (2001), A plot based method for rapid estimation of forest canopy chemistry, Can. J. Forest Res., 31, 549-555.

Song, X., M. M. Barbour, G. D. Farquhar, D. R. Vann, and B. R. Helliker (2013), Transpiration rate relates to within- and across-species variations in effective path length in a leaf water model of oxygen isotope enrichment, Plant Cell Environ., 36, 1338-1351.

Sullivan, P. F., and J. M. Welker (2007), Variation in leaf physiology of Salix arctica within and across ecosystems in the High Arctic: Test of a dual delta C-13 and delta O-18 conceptual model, Oecologia, 151, 372-386.

Tang, J., P. V. Bolstad, B. E. Ewers, A. R. Desai, K. J. Davis, and E. V. Carey (2006), Sap flux-upscaled canopy transpiration, stomatal conductance, and water use efficiency in an old growth forest in the Great Lakes region of the United States, J. Geophys. Res., 111, G02009, doi:10.1029/ 2005JG000083.

Tang, X., et al. (2014), How is water-use efficiency of terrestrial ecosystems distributed and changing on Earth?, Sci. Rep., 4, 7483, doi:10.1038/ srep07483.

Tardieu, F., and T. Simonneau (1998), Variability among species of stomatal control under fluctuating soil water status and evaporative demand: Modelling isohydric and anisohydric behaviours, J. Exp. Bot., 49, 419-432.

Valentini, R., D. Epron, P. De Angelis, G. Matteucci, and E. Dreyer (1995), In situ estimation of net $\mathrm{CO}_{2}$ assimilation, photosynthetic electron flow and photorespiration in Turkey oak (Q. cerris L.) leaves: Diurnal cycles under different levels of water supply, Plant Cell Environ., 18 631-640, doi:10.1111/j.1365-3040.1995.tb00564.x.

Valentini, R., et al. (2000), Respiration as the main determinant of carbon balance in European forests, Nature, 404, 861-865.

Wang, K., and R. E. Dickinson (2012), A review of global terrestrial evapotranspiration: Observation, modeling, climatology, and climatic variability, Rev. Geophys., 50, RG2005, doi:10.1029/2011RG000373.

Warren, C. R. (2008), Stand aside stomata, another actor deserves centre stage: The forgotten role of the internal conductance to $\mathrm{CO}_{2}$ transfer, J. Exp. Bot., 59(7), 1475-1487.

Wehr, R., J. W. Munger, J. B. McManus, D. D. Nelson, M. S. Zahniser, E. A. Davidson, S. C. Wofsy, and S. R. Saleska (2016), Seasonality of temperate forest photosynthesis and daytime respiration, Nature, 7609(534), 680-683.

Wright, I. J., et al. (2004), The worldwide leaf economics spectrum, Nature, 428, 821-827.

Xiao, J. F., et al. (2013), Carbon fluxes, evapotranspiration, and water use efficiency of terrestrial ecosystems in China, Agric. For. Meteorol., $182(183), 76-90$.

Xiao, J. F., et al. (2014), Data-driven diagnostics of terrestrial carbon dynamics over North America, Agric. For. Meteorol., $197,142-157$.

Xu, M., et al. (2014) Effects of climatic factors and ecosystem responses on the inter-annual variability of evapotranspiration in a coniferous plantation in subtropical China, PLoS One 9(1), e85593, doi:10.1371/journal.pone.0085593.

Zhang, Y., M. Xu, H. Chen, and J. Adams (2009), Global pattern of NPP to GPP ratio derived from MODIS data: Effects of ecosystem type, geographical location and climate, Global Ecol. Biogeogr., 18, 280-290, doi:10.1111/j.1466-8238.2008.00442.x.

Zhu, J., and X. Zeng (2015), Comprehensive study on the influence of evapotranspiration and albedo on surface temperature related to changes in leaf area index, Adv. Atmos. Sci., 32, 935-942. 